\title{
3D DNA Nanostructures: The Nanoscale Architect
}

\author{
Daniel Fu (1) and John Reif * (1)
}

check for

updates

Citation: Fu, D.; Reif, J. 3D DNA Nanostructures: The Nanoscale

Architect. Appl. Sci. 2021, 11, 2624.

https://doi.org/10.3390/app11062624

Academic Editor: Alexander E.

Marras

Received: 12 February 2021

Accepted: 9 March 2021

Published: 16 March 2021

Publisher's Note: MDPI stays neutral with regard to jurisdictional claims in published maps and institutional affiliations.

Copyright: (c) 2021 by the authors. Licensee MDPI, Basel, Switzerland. This article is an open access article distributed under the terms and conditions of the Creative Commons Attribution (CC BY) license (https:// creativecommons.org/licenses/by/ $4.0 /)$.
Department of Computer Science, Duke University, Durham, NC 27708, USA; daniel.fu@duke.edu

* Correspondence: reif@cs.duke.edu

\begin{abstract}
Structural DNA nanotechnology is a pioneering biotechnology that presents the opportunity to engineer DNA-based hardware that will mediate a profound interface to the nanoscale. To date, an enormous library of shaped 3D DNA nanostructures have been designed and assembled. Moreover, recent research has demonstrated DNA nanostructures that are not only static but can exhibit specific dynamic motion. DNA nanostructures have thus garnered significant research interest as a template for pursuing shape and motion-dependent nanoscale phenomena. Potential applications have been explored in many interdisciplinary areas spanning medicine, biosensing, nanofabrication, plasmonics, single-molecule chemistry, and facilitating biophysical studies. In this review, we begin with a brief overview of general and versatile design techniques for 3D DNA nanostructures as well as some techniques and studies that have focused on improving the stability of DNA nanostructures in diverse environments, which is pivotal for its reliable utilization in downstream applications. Our main focus will be to compile a wide body of existing research on applications of 3D DNA nanostructures that demonstrably rely on the versatility of their mechanical design. Furthermore, we frame reviewed applications into three primary categories, namely encapsulation, surface templating, and nanomechanics, that we propose to be archetypal shape- or motion-related functions of DNA nanostructures found in nanoscience applications. Our intent is to identify core concepts that may define and motivate specific directions of progress in this field as we conclude the review with some perspectives on the future.
\end{abstract}

Keywords: structural DNA nanotechnology; DNA origami; DNA-template synthesis; nanomechanics; drug delivery; nanofabrication

\section{Introduction}

Architecture is a concept typically associated with human-scale engineering, but it aptly applies to the technologies of evolved natural materials as well. The eons-long evolution of natural constructs has created a wide diversity of molecular-scale housings and machinery which function to promote biodiversity and biological complexity. One may not typically think of viral capsids, membranes, vesicles, microtubules, and biomineralization as rooms, buildings, districts, highways, and concrete, but for their biomolecule citizens, this is the architecture that builds their cities. We admire that the artistry of cellular architecture often relates to their purpose, as geometries and aspect ratios can directly affect surface-volume ratios, the biochemical activity of cells [1], or also serve as important modes of passive filtration [2,3]; the complexity of which is daunting, and no effort has been spared to understand, replicate, and utilize nature's evolved architectures for the ambitions of human technology. Progress thereof increasingly provides us the nuts and bolts of nanoengineering to architect and send artificial nanomachines to interact with nature's moieties, which in turn promotes a cycle of better understanding and inventing nanotechnologies.

A prime example has been the field of DNA nanotechnology. Exciting research is ongoing to show that DNA could be a biomaterial that ushers a new paradigm of nanoengineering, serving an unexpected architectural purpose in nanoscience in constrast to its genetic origins. In comparison to alternatives, DNA nanotechnology is appealing for 
its simplicity and functional generality; prescriptive design of the Watson-Crick bonding reactions of only DNA reagents yields a vast complexity of computational and structural architectures. Furthermore, DNA is biocompatible, soluble, and its chemistry is amenable to the attachment of functional groups consisting of various other organic and inorganic materials. The prospect of free-form structural self-assembly is enticing, and fundamentals of geometric design in DNA nanotechnology have also inspired the same principles to be investigated for RNA [4] or proteins [5,6] as the base material.

Organization of Review: This review focuses on structural DNA nanotechnology, that is, the subfield concerned with the design and operation of self-assembled nanoparticles composed primarily of DNA, or DNA nanostructures. The goal of the review is to corroborate the significance of the exact mechanical design of DNA nanostructures and their properties, such as shape, stiffness, elasticity, and actuation, towards deliberate physical control of nanoscale phenomena. This review will first recall various techniques that exist for designing static 3D DNA nanostructures for specific geometric categories, and we stress the importance of software packages for their design and simulation. We will also discuss emerging techniques for composing static components into dynamic mechanical assemblies. Next, we summarize several studies on the stability of DNA nanostructures that, in practice, is necessary knowledge to reliably utilize the aforementioned DNA nanostructures in their downstream applications. Finally, we devote a significant portion of this review on the discussion of applications, divided into three categories, namely encapsulation, surface templating, and nanomechanics, and we propose that each identifies a common, archetypal function of 3D DNA nanostructures present in nanoscience applications (Figure 1). We do not suggest that these may be the only categories or that applications can not span multiple categories, but that they may help us navigate the strengths of structural DNA nanotechnology or reveal new directions of so far unrealized archetypal biomimicry of natural constructs that the field may be well-suited to.

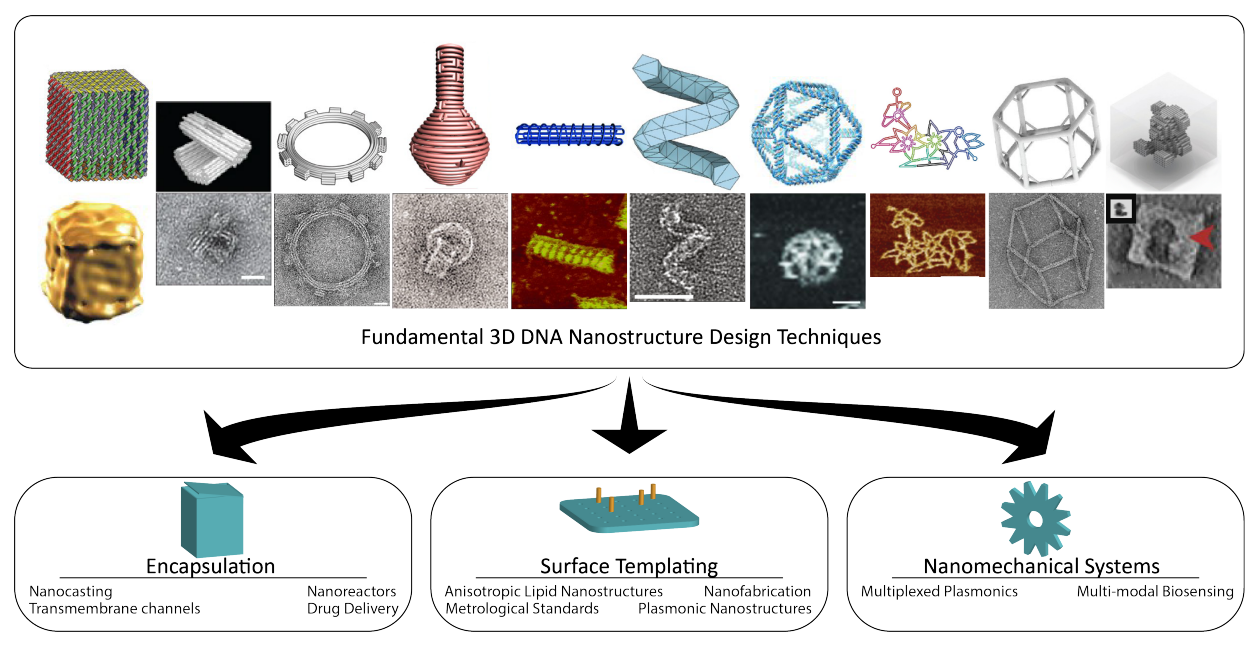

Figure 1. Mechanical designs of 3D DNA nanostructures are applied to a wide range of interdisciplinary areas through three archetypal functions of nanoscale geometric design. Fundamental design techniques of 3D DNA nanostructures (left to right): Assembly from flat shapes (reprinted with permission from Springer Nature [7]); DNA origami blocks (reprinted with permission from Springer Nature [8]); Curved and twisted DNA origami bundles (reprinted with permission from AAAS [9]); Single-layer curved DNA origami (reprinted with permission from AAAS [10]); Gridiron curved DNA origami (reprinted with permission from AAAS [11]); Polygonal DNA origami routed by an Eulerian circuit solution (Benson et al. reprinted with permission from Springer Nature [12] and Veneziano et al. reprinted with permission from AAAS [13]) or multi-arm junctions (reprinted with permission from Springer Nature [14]); Piecewise polyhedral DNA nanostructures (reprinted with permission from AAAS [15]); DNA bricks (reprinted with permission from Springer Nature [16]). Their designs can be used to encapsulate a cavity for protection or transportation of other molecules, for the arrangement or templated assembly of other molecules based on the geometric orientation provided by the DNA nanostructure, or using tunable, dynamic nanomechanical features of DNA nanostructures to measure or manipulate other molecules. 


\section{3D DNA Nanostructure Design}

\subsection{History}

\subsubsection{DNA Tiling Lattices}

Nadrian Seeman first published the seminal observation that DNA could serve a structural purpose in 1982, where it was envisioned that repeating units of branching DNA junctions could hybridize to form a stiff 3-dimensional lattice to facilitate crystallographic study of other molecules [17]. This became the inspiration for DNA tiles, the earliest general technique for structural DNA design. More generally, a DNA tile is a DNA nanostructure that is self-assembled from a small number of single-stranded DNA (ssDNA) that hybridize together with stabilizing Holliday junctions known as crossovers. Once assembled, the DNA tiles have ssDNA (termed sticky ends) which allow the DNA tile to further selfassemble into DNA nanostructures known as DNA lattices, which have been used to build 1D and 2D DNA tiling assemblies and lattices for molecular-scale computation. Seeman also demonstrated the first 3D DNA cube using 8 branching junctions [18]. However, yields, sizes, and shapes of early DNA nanostructures self-assembled by DNA tiles were limited. Persistent effort [19,20] since then has yielded micron-scale DNA crystals [21], which to date are the largest DNA nanostructures to be synthesized, but those are so far limited to rhombohedron shapes. The self-assembly of patterns by DNA tiles has proved to be quite complex, as shown in Sierpinski triangle assemblies by Rothemund, Papadakis, and Winfree [22], which computed mod 2 sums within the assembly, forming a fractal-like 2D pattern. However, the class of possible geometries of DNA tiling assemblies still remains restricted to algorithmic patterns.

\subsubsection{DNA Origami}

The shift into the current paradigm of DNA nanostructure design occurred when Paul Rothemund developed a technique now known as DNA origami [23]. A long piece of ssDNA, known as the scaffold strand, winds through a raster of the shape while hundreds of short ssDNA span and hybridize to spatially adjacent, non-consecutive regions of the scaffold strand according to Watson-Crick base pairing rules, thus tying them spatially together. As the staple strands bind, duplexes are formed which stiffen the structure to form the shape, forming a series of coplanar, anti-parallel helices bound by crossovers. This concept was a very important conceptual breakthrough in the field of DNA nanotechnology and significantly improved the size, yield, and shape complexity of DNA nanostructures. Although initially demonstrated for designing only 2D shapes, the DNA origami technique has since been extensively developed as the underlying strategy for many subsequent derived techniques for designing increasingly complex 3D shapes.

\subsection{Fundamental Techniques for Design of 3D DNA Nanostructures \\ 2.2.1. DNA Origami Blocks}

Following the advent of DNA origami, the Shih group made the first foray towards a general design method for 3D DNA origami [9]. This strategy can be thought of as folding a flat 2D DNA origami at creases between adjacent helices to create a stacked structure of multiple planes of 2D DNA origami and adding crossovers that span both in-plane and between planes to hold the structure together. Further work by the Shih and Yan groups also introduced various different organizations of the cross-section of DNA origami blocks, such as the honeycomb lattice, as initially demonstrated, but also square [24] and hybrid (of both square and honeycomb) [25] lattices. Around this time, unique designs showcasing a growing proficiency for designing DNA origami nanostructures were also demonstrated. For example, using flat 2D DNA origami as the faces of simple polygonal shapes such as cubes [7,26] or tetrahedrons [27], or unique artistic structures such as a Möbius strip [28] and tensegrity structures [29], which are truly a testament to the structural versatility of DNA nanostructures. As with the other techniques we will discuss here, the increasing scale of 3D structures also solicited the creation of CAD software to assist in their design, 
and the software package caDNAno [30] has been the longstanding, dominant option for structures with cross-sections of parallel helices.

\subsubsection{Curved DNA Origami}

Geometric complexity continued to improve as the Shih group demonstrated smooth global curvature and twist, as opposed to hitherto straight geometries, along the axis of a helix bundle, which is a rod-like structure of anti-parallel helices arranged in a packed square or honeycomb lattice cross-section and has become an archetypal DNA nanostructure. This was done via a series of insertions and deletions [9], which are modifications in the crossover placement a few base pairs nearer or farther than a placement that would correspond most closely to the native winding of B-form DNA (10.5 bps/turn). In doing so, a helix became locally overwound or underwound, creating strain. Globally, the relaxation of the structure to satisfy the buildup of strain translated to twist or curvature of the bundle depending on the chosen distribution of insertions and deletions. This technique inspired another technique by the Yan group for making curved, hollow, enclosing DNA origami nanostructures. By connecting the endpoints of a duplex together, it became a cyclic structure. In combination with a duplex's persistence length, the distribution of strain along the duplex formed a circle, and this shape was reinforced by its similarly shaped adjacent helices. Modulating the lengths of each duplex of the flat 2D sheet corresponded to changing the circumference, and by utilizing the full availability of dihedral angles, the surface topology of the nanostructure could be designed to resemble shapes such as spheres, ellipsoids, toroids, or flasks [10]. This concept was later further extended by the same group using gridiron designs, which routed the scaffold and placed staple strands such that helical axes could run perpendicular to each other to reinforce shape and curvature [11]. Thus far, the Tiamat software [31] has been the leading option for designing such structures in an open 3D space.

\subsubsection{Wireframe DNA Origami}

Shape complexity leaped forward as the Bathe, Yan, and Högberg groups each embarked on unique demonstrations of DNA nanostructures capable of rendering a polyhedral mesh [12-14]. The crux of this problem was how to route the scaffold such that every edge of the polyhedron was included, eventually concluding that any such scaffold routing must follow a Eulerian circuit solution and manipulate the number of permissible repeated edge traversals to satisfy such a solution. These works also evaluated how to adjust edge lengths such that they would correspond to the correct full- or half-turn crossover positions in B-form DNA for stable crossover placement. Polyhedral strutures have established the largest variety of shapes, especially with subsequent improvements to their stability and the availability of software to automate the scaffold routing process $[12,13,32,33]$. The Yin group also demonstrated an alternative method for polyhedral shape formation, that while lacking algorithmic foundations [15], has the advantage of scalability due to the modular nature of the design method escaping the size limitations of using only a single scaffold strand for a structure. Several software tools have been designed, each to satisfy an increase in the structural complexity of polyhedral DNA origami nanostructures. Software packages DAEDALUS [13] and vHelix [12] served as the earliest methods for designing polyhedral DNA nanostructures. PERDIX [33] later addressed the complexity of 2D designs, and TALOS [32] for polyhedral structures with thicker helix bundle edges which required more complex algorithms to solve for the scaffold routing.

\subsubsection{DNA Bricks}

While the DNA origami methodology has been a fundamental mainstay in most strategies, the DNA bricks technique pioneered by the Yin group has been one that has been otherwise successful without it. DNA bricks construct structures without the use of any scaffold strand, instead opting to only use short ssDNA referred to as bricks. Each brick is a pair of same length antiparallel helices joined by a phosphate linkage. Each 
helix of the brick is split into 2 equal length domains, such that the brick has a total of 4 domains, and each domain is a consistent length regarded as the motif. Motifs are either 8 or $13 \mathrm{nt}$, and the choice of motif affects the scale of designed structures due to the number of unique sequences possible for a specific length of DNA, as well as yields and melting temperature. In a simple one-pot synthesis, the numerous strands self-assemble with each strand representing a small volume of the structure like bricks filling in a shape [34]. This technique has been shown to scale up to megadalton scales with high shape complexity, which was also accompanied by the release of its own software tool Nanobricks [16].

\subsection{Scalability}

In general, there has been a trend towards scaling up production and size of 3D DNA nanostructures across all techniques. One strategy has been to pursue improvements to scaffold strand size and customization. In order to create larger, more diverse DNA origami as single, one-pot syntheses, either longer scaffolds or many orthogonal scaffolds are required, and avenues such as re-engineering bacteria and enzymatic toolkits to those ends [35-37] have been investigated. Doing so can suppress cost, relieve design limitations to improve the practicality of 3D DNA nanostructures across broader size scales, and also ensure immunocompatibility of DNA nanostructures for in vivo applications. For more information on this topic we suggest readers consult an excellent previous review [38].

On the other hand, rather than facing the challenges associated with longer scaffold strands, other novel techniques instead rely on some form of hierarchical assembly. The Dietz group demonstrated gigadalton-scale DNA nanostructures by utilizing self-assembly techniques upon an already assembled DNA origami component to create large, polygonal DNA nanostructures [39]. Each component was a V-shaped structure (V-brick) that could join to others by attachment sites on their flat sides. A tripod structure of three V-bricks together translated to the angle of the vertex it would represent in a 3D polygonal shape, such that polygonal structures would self-assemble towards an energetically favorable configuration matching the number of vertices necessary to form a closed shape. The Yan and Reif groups have proposed using Meta-DNA [40,41] as another route towards scaling up the size of DNA nanostructures. Meta-DNA are 3D DNA origami nanostructures that have been constructed to resemble both the shape and Watson-Crick base pairing rules of the standard nucleotides of DNA. These Meta-DNA nucleotides hierarchically assemble into double helix superstructures resembling DNA which can then be used to emulate DNA origami designs but at a magnified scale.

In comparison to depending on specific hybridization reactions to assemble multicomponent structures, which can be restrictive and difficult to reverse, alternative methods have also been demonstrated to have the propensity to assemble large, complex 3D DNA nanostructures, such as by using base stacking or shape-complementary binding [42]. As already mentioned, extended methods of other standard techniques, such as for wireframe DNA origami [32,33] or DNA bricks [16], have also looked to making their own methods suitable for larger and more mechanically rigid designs. Assemblies utilizing crystallographic regularity of DNA origami nanostructures can also provide large templates for the assembly of guest molecules [43,44].

\subsection{The Role of Molecular Dynamics Simulations in Design}

Molecular dynamics simulations have been a significant development in the computational aspects of DNA nanostructure design, as they provide faster, cheaper feedback and insight into the behavior of DNA nanostructures. The development of coarse-grained molecular dynamics modelling tools such as CanDo provided by the Bathe group [45], oxDNA provided by the Doye and Louis groups [46] and NAMD provided by the Aksimentiev group [47] has greatly alleviated challenges in designing and testing DNA nanostructures. It has since become possible to simulate large DNA origami [47-50] with molecular granularity. These tools can simulate the diffusive movement of strands, their hybridization, as well as their physical properties that may rely on bond strength, system 
temperature, or ionic concentrations, and thus can provide information on the shape and stiffness of designed DNA nanostructures in an expected environment. This route of study can present a preview of results that have also been revealed via challenging, but increasingly insightful, characterization by imaging techniques such as cryo-EM [51,52].

\section{Dynamic Mechanical Control and Motion}

One of the incredible material properties of DNA is that it simultaneously fulfills numerous capabilities as a structural, programmable, and addressable material. DNA nanostructures can be integrated with small modules of few strands that can implement DNA computing, from which dynamic mechanical behavior in DNA nanostructures, which we will herein refer to as DNA nanomechanics, can be implemented and controlled. Dynamic systems can be described as either autonomous or non-autonomous and also differentiate between active and passive motion (Figure 2). Autonomous systems are able to move through consecutive states of the system without any additional inputs or outside influence, while non-autonomous systems may need some externally provided trigger, such as light or an injection of molecular signals. Systems with active motion typically feature some source of tensile forces constraining the system to a specified set of distinct physical states, while passive motion relies on unconstrained components to float to desired positions via diffusion. The number of strategies to control DNA nanostructure-based motion are greatly varied and often integrate other molecules.

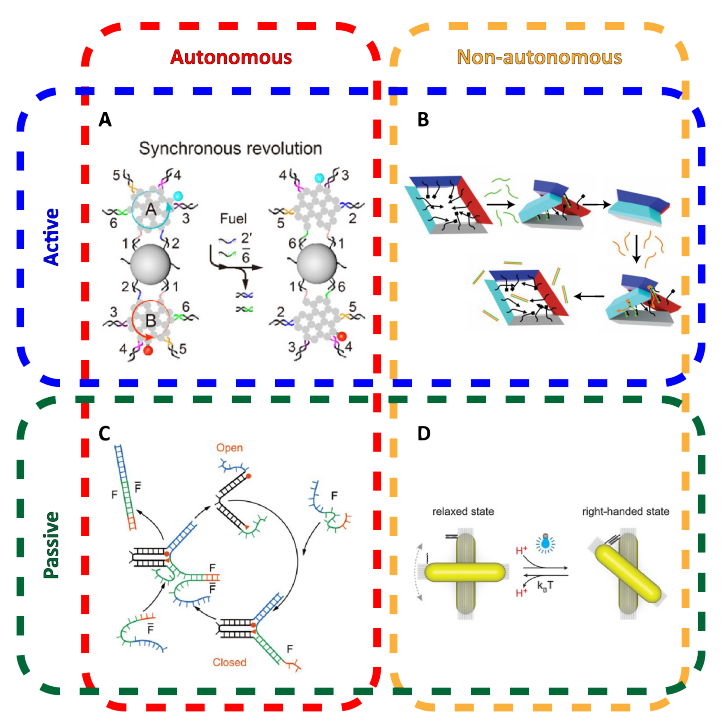

Figure 2. Examples of classes of dynamic DNA systems. (A) A gear-like system resembles the motion of a DNA walker upon a track embedded upon the surface of a gold nanoparticle. The system autonomously transitions between physical states of rotation with respect to the central gold nanoparticle by consuming ssDNA fuel (reprinted with permission from AAAS [53]); (B) The operation of a DNA origami Bennett linkage has defined physical conformations but requires an injection of strands to progress the state of the system via strand displacement (reprinted with permission from National Academy of Sciences [54]); (C) A DNA tweezer cycles between opened and closed states by consuming fuel. Its closed state is enforced by the rigidity of duplex DNA. However, without any mechanical stress to bias the opened state, the system only reaches the state via diffusive movement of its components (reprinted with permission from Springer Nature [55]); (D) The rotational configuration of two gold nanorods attached to their respective DNA origami bundles is controlled by an external light source that affects the formation of a DNA triplex link between the bundles. While the link is inactive, the angular relationship between the nanorods is no longer fixed as the components will rotate in the relaxed state (reprinted with permission from Wiley-VCH [56]). 


\subsection{Controlling DNA Nanomechanics}

Most logic operations or state transitions for operating nanomechanical DNA devices will depend on toehold-mediated strand displacement (TMSD), which is a fundamental technique that can integrate DNA nanostructures with signals and processing power from the rich field of DNA computing, as has been thoroughly reviewed in previous articles $[57,58]$. In TMSD, a duplex is formed where one strand is slightly longer than the other, which exposes a short region of unhybridized DNA known as the toehold. Another strand with a sequence domain complementary to the toehold can initially bind to this region. Then, if the incoming strand is further complementary to the remaining sequence of the duplex, it will competitively displace the currently bound shorter strand of the duplex via branch migration.

One of the most common uses of this principle is to switch a hollow DNA nanostructure passively between its opened and closed states. These typically feature two separable pieces that are pinned together at two points: a hinge and a TMSD-based latch. Upon the latch being released, one half begins to float away while fixated at the hinge, as if swinging open. The overall structure can also be designed in the open configuration, such that the hinge is pre-strained to return to that configuration when the latch is undone. Moreover, strand displacement works regardless of whether the displacing molecule is the complementary oligonucleotide [7] or if the toehold is part of an aptamer sequence that specifically binds a target molecule [59]. These are typically examples of passive motion, that is, the latch determines a state (open or closed), but the movement of pieces relies on diffusion. Thus, while the logical state of the structure is determined, its actual physical state may not be.

TMSD can also be used to implement an autonomous system where a DNA device can move through sequential states by a likewise sequence of TMSD reactions. The earliest demonstrations of autonomously transitioning through configurable physical states in DNA nanostructures include a DNA tweezer by Yurke et al. [55] and a DNA walker by the Reif group in collaboration with the Turberfield group [60]. In the presence of fuel strands, which were not inputs but a consumed reactant for the TMSD reactions to repeatedly occur, a series of distinct hybridizations could be triggered to autonomously convert the DNA system through a series of distinct physical states. However, the physical scale of such demonstrations was otherwise small.

\subsection{Configuring Physical States of DNA Origami-Scale Systems}

An important design feature for implementing and controlling actuation in DNA nanostructures will be to relate the degrees of motion to some easily quantifiable, direct stimulus. A most straightforward solution is for mechanical deformations to be determined by individual ssDNA within the structure, so that simple metrics, such as its presence or length, induce predictable mechanical changes for the entire structure.

One strategy to do so as shown by the Kim and Castro groups has been to tether points on two distant regions of the structure with the tension of a suspended ssDNA "spring", so the length of the string modulates the bending of the structure [61,62] (Figure 3A). An extension of this concept also by the Castro group demonstrated more complex mechanisms that could slide and pivot in a fashion very similar to human-scale machines such as crank-sliders and Bennett linkages [54]. Mechanically, the elasticity of DNA [63] plays a major role in coercing the energy landscape of DNA origami assemblies into constrained physical configurations. The Murata group demonstrated a more modular strategy for implementing curved DNA origami bundles by consolidating regions for inducing curvature such that its mechanical deformation can be isolated to specific strands. A bundle is designed with segmentation such that it becomes a series of extruding piers and gaps, while continuous only through a thin backbone. Each pair of adjacent piers can then be tethered by a ssDNA linker of selected length corresponding to the desired curvature [64] (Figure 3B). A DNA nanostructure with cascading transformations was also demonstrated by the Ke group. A small structural DNA unit called an anti-junction was designed that 
could transform from a horizontally elongated form to a vertically elongated form in response to a ssDNA trigger. These units could be chained in a lattice, where subsequent units could be triggered by previous units in their series. A single trigger to the first unit would then produce a domino-like transformation of the structure observable by AFM [65] (Figure 3D). In work by the same group, modular units of DNA origami contained hairpin loops built into their strand sequences. Invading ssDNA could bind to the loop as a toehold and displace an existing strand of the structure, which stretched the helix using the excess bases originally hidden in the loop. Tailored placement of this operation could induce programmable transformation of the same structure into elongated, twisted, and curved variants [66].

A

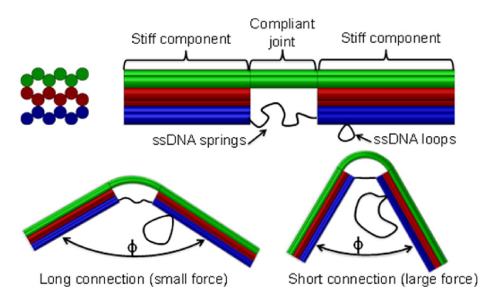

B

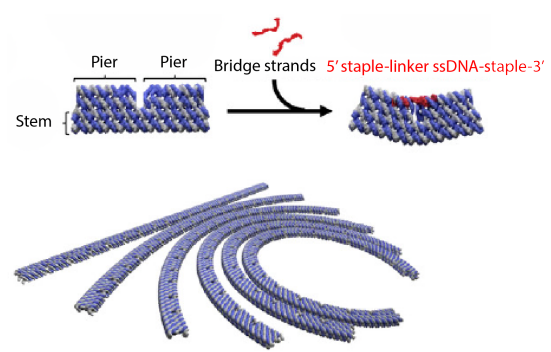

C

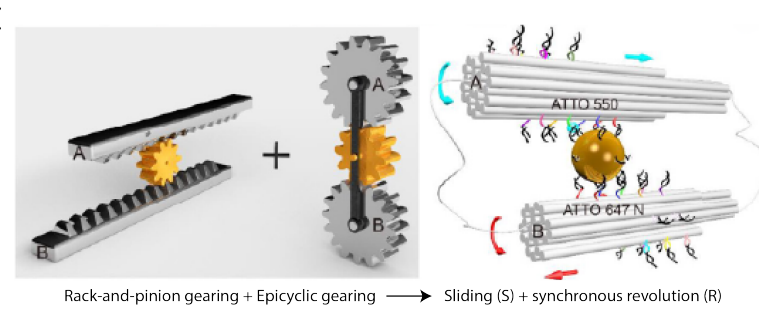

D

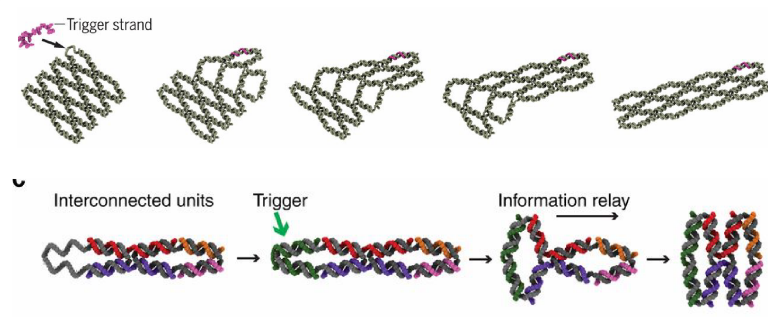

Figure 3. Nanomechanics implemented by DNA nanostructures. (A) Controlled angle of a hinged DNA nanostructure via an elastic ssDNA spring (reprinted with permission from ACS Publications [61]); (B) Modular deformation of a long DNA origami bundle. Linker strands span piers to induce local bending, which sums to global curvature (reprinted with permission from Wiley-VCH [64]); (C) Rotational and sliding gear motions of DNA origami bundles with respect to a central DNA nanorod (reprinted with permission from AAAS [53]); (D) DNA antijunction units composed into lattice arrays that transmit cascading changes through the structure (reprinted with permission from AAAS [65]).

In demonstrating more DNA analogues of simple machines, the Liu group showed the design of both rotating and sliding gear mechanisms [53] (Figure 3C) by designing DNA nanostructures that "walked" with respect to a central gold nanorod acting as a cyclic track. The operation was akin to traditional DNA walkers. Two DNA origami bundles were placed in parallel with a gold nanorod via distinct columns of sequences protruding from each side of each hexagonal DNA bundle. By consuming fuel, the extended sequences that encircle the DNA bundle could sequentially bind to complementary sequences extending from the central gold nanorod to induce rotation of the DNA nanostructure in place or with respect to the gold nanorod.

\subsection{Control Sources}

In order to bridge interaction between a human observer and nanomechanical DNA systems, scientists have relied on light, $\mathrm{pH}$, temperature, ion concentration, or externally applied fields to deliberately control activity. Molecules that have photo-cleavable bonds or photo-switchable configurations can be used in DNA nanomechanics to implement light-responsiveness. For example, azobenzene that is inserted into oligonucleotides responds to UV-light irradiation by switching between trans and cis formations that disrupt hybridization via steric hindrance. An azobenzene latch implemented into a DNA origami capsule could be used for the light-responsive release of molecular cargo [67] or modulate the reconfiguration of components in dynamic DNA-templated plasmonic assemblies [56]. 
Kohman et al. also demonstrated the incorporation of ortho-nitrobenzyl, which is photocleavable, to actuate the opening of a spherical DNA origami capsule [68] (Figure 4A). The Willner group demonstrated both light-responsiveness using azobenzene and ionresponsiveness using DNAzymes in unlocking latches upon a 2D DNA origami to actively create a nanohole in the structure [69]. DNA nanostructures can further be made sensitive to $\mathrm{pH}$ using i-motifs [70] or to temperature by integrating temperature-sensitive polymers into the same positions as elastic ssDNA springs to restrain the relative position of two DNA origami sections [71] (Figure 4C). The Simmel group demonstrated control over the rotation of a DNA origami bundle arm using an electrical field, which could align the arm due to the intrinsic charge of DNA [72] (Figure 4B).

A

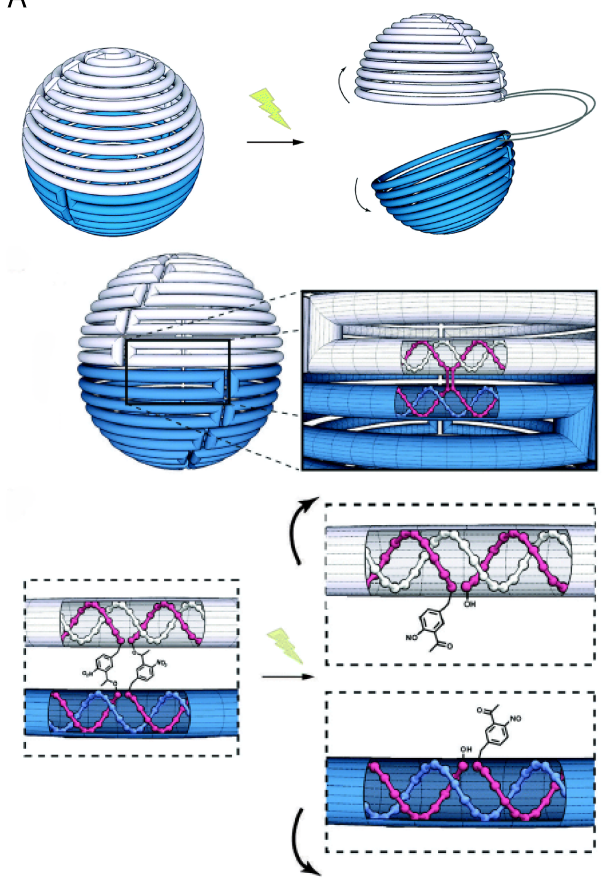

B

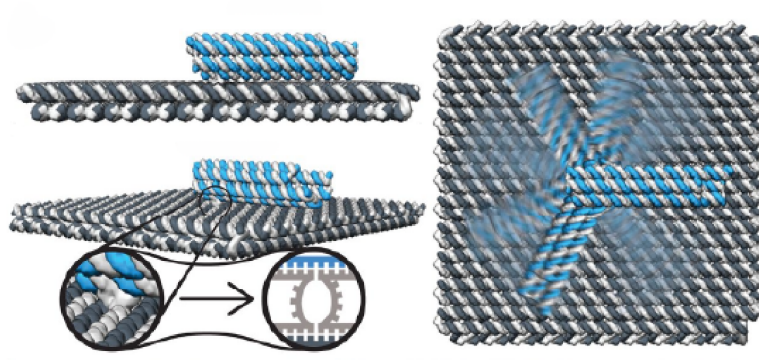

C

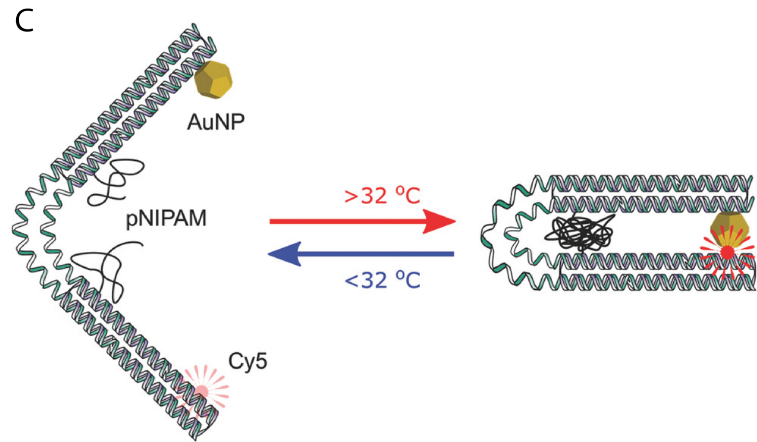

Figure 4. Signal-responsive actuation of DNA nanomechanics. (A) A light-responsive spherical DNA capsule with a photo-cleavable site (reprinted with permission from The Royal Society of Chemistry [68]); (B) A DNA origami arm that can be controlled by an external electric field (reprinted with permission from AAAS [72]); (C) A hinged DNA nanostructure that places polymers with temperature-responsive hydrophobicity on opposite facing sides of the hinge. Above a specific temperature threshold, the polymers aggregate due to hydrophobic interactions and pull the DNA nanostructure into a closed conformation (reprinted with permission from Wiley-VCH [71]).

\section{Stability and Environmental Conditions}

DNA origami is typically synthesized in a standard molecular biology buffer solution of Tris and EDTA $(\mathrm{pH} 8)$ in the presence of divalent cations, typically $\mathrm{Mg}^{2+}$, that offset repulsive electrostatic interactions due to the intrinsic negative charge in the DNA phosphate backbone which may otherwise interfere with the stability of designed DNA nanostructures. However, this environment often differs in targeted applications. For in vivo applications, physiological fluids typically have $\mathrm{Mg}^{2+}$ concentrations that are too low to maintain DNA nanostructure stability and nucleases that may degrade DNA nanostructures. It has also been shown that DNA nanostructures are ultimately digested by lysosomes [73] rather than having penetrated their desired cell target. Applications related to nanofabrication may also involve organic solvents, which can make conditions too harsh for DNA nanostructures to survive. Notably, while surface-deposited DNA nanostructures have been shown to be stable in the presence of organic solvents, they rapidly degrade in solution [74]. 
The Dietz group has shown that it is still possible to synthesize DNA nanostructures and maintain their stability without the presence of $\mathrm{Mg}^{2+}$ (whose presence in solution can be unfavorable to many biological agents), and instead can rely on $\mathrm{Na}^{+}$, which is much more widely compatible [75]. Joint work by the Keller and Linko groups investigated the effect of lowering $\mathrm{Mg}^{2+}$ concentration for a comparison between a few simple DNA origami nanostructures. It was noted that dense structures, such as a $24 \mathrm{HB}$, may require higher concentrations of $\mathrm{Mg}^{2+}$ to remain stable due to higher density of internal negative charge. Additional work by the Schlierf, Keller, and Liu groups has also thoroughly documented DNA nanostructure stability with respect to changes in temperature or harsh chemicals $[74,76]$ and are good benchmark references for areas where DNA nanostructures may need to be improved.

Attacking this problem from another perspective has been to bolster the stability of DNA nanostructures by design to withstand harsher conditions. Stricter design criteria for the placement of crossovers and nicks have been shown to increase stability and yields of DNA origami [24,25,77]. A design strategy by the Dietz group utilized a technique with strong covalent cyclobutane pyrimidine dimer (CPD) bonds which form between proximally close thymidines upon UV irradiation. By adding thymine bases at specific staple sequence locations within the DNA origami design, UV irradiation could induce a network of strong covalent bonds throughout the structure to strengthen it [78]. Joint work by the Ding and Du groups have shown that shape and size of DNA nanostructures may have some effect on the degradation rate of simple, monolithic structures in an in vivo rat model, or be at least sufficient enough to achieve passive buildup of anti-cancer drugs at a tumor site [79]. However, it does not indicate that structure-dependent functions could survive.

Several other strategies rely on coating the DNA nanostructure with other molecules that may either serve to stiffen, protect, or camouflage the structure. Joint work between the Fan and Yan groups developed a method to coat DNA origami with silica in biomimicry of biomineralization techniques of seafaring diatoms [80] (Figure 5A) and showed that a "silicised" tetrahedron DNA nanostructure resisted deformations from physical stress applied by an AFM tip. Further studies on this method by the Kuzyk group later showed that silicised DNA nanostructures also resisted degradation by nucleases and organic solvents [81]. Collaborative work by the Yin and Strano groups demonstrated DNA origami used as lithography masks, but also showed that they had to be metallized prior to an etching step to maintain their shape [82]. For in vivo applications, a popular strategy has been for DNA nanostructures to protect or camouflage themselves with materials that are known to resist digestion or improve cellular uptake. Coatings have included peptoids [83] (Figure 5C), cationic polymers [84], oligolysine [85], and proteins [86] (Figure 5B), which has each been shown to withstand controlled physiological conditions. We have only provided a very brief summary here, but for a more in-depth insight on the current state of DNA nanostructure stability, we recommend readers to previous reviews $[87,88]$. 

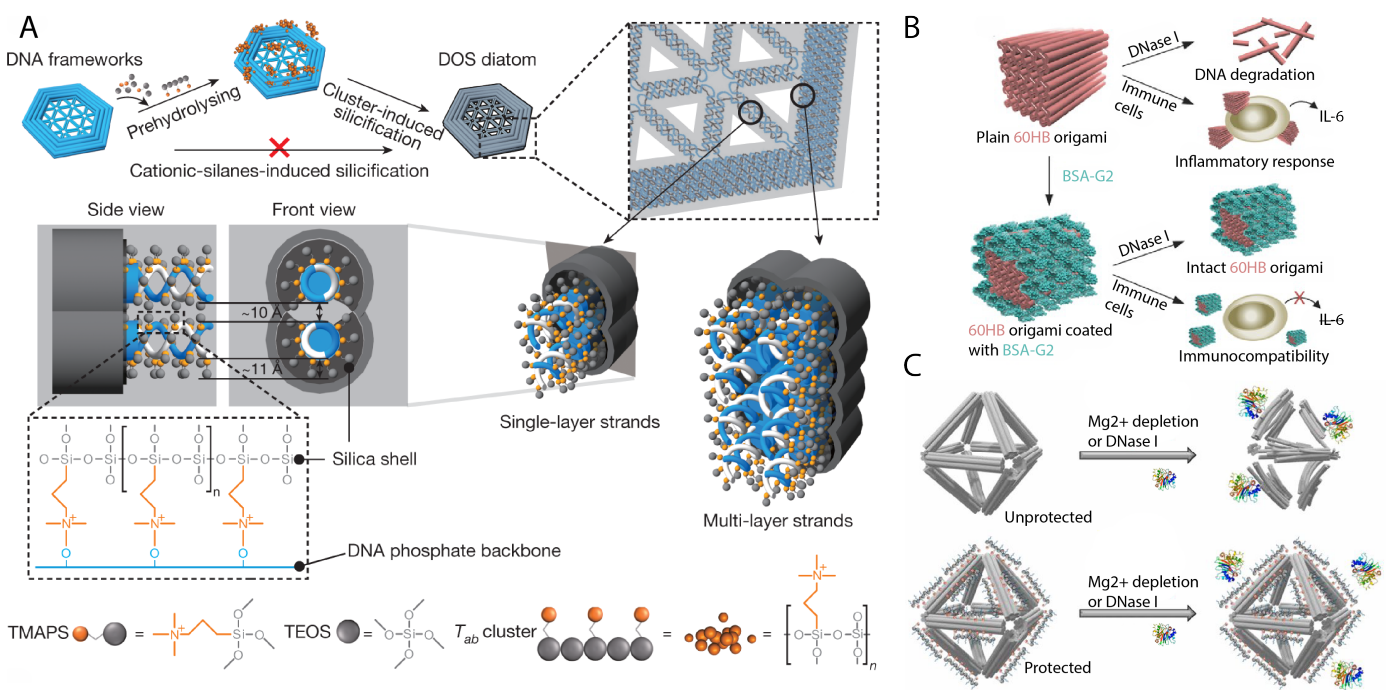

Figure 5. Reinforcement of DNA nanostructures via coating. (A) Applying a coat of silica on DNA nanostructures has been shown to increase stiffness and stability (reprinted with permission from Springer Nature [80]); (B) Protein coatings have been shown to increase immunocompatibility of DNA nanostructures as well as resist degradation by DNase I (reprinted with permission from Wiley-VCH [86]); (C) Peptoid coatings maintain stability of DNA nanostructures in low $\mathrm{Mg}^{2+}$ concentrations and in the presence of DNase I (reprinted with permission from National Academy of Sciences [83]).

\section{Applications}

3D DNA nanostructures have been demonstrated across a wide field of potential applications. Various works demonstrate how the prescribed shape and motion of DNA nanostructures may redefine our interaction with the nanoscale, either through biomimicry or the translation of macroscale engineering into nanoscale equivalents. We divide these into a few fundamental conceptual categories, namely encapsulation, surface templating, and nanomechanics, as a framework for our discussion.

\subsection{Encapsulation}

We refer to encapsulation as the concept of designing DNA nanostructures that form dense, continuous walls to produce a functional cavity. In addition, it should also be possible to selectively control the permeation of specific molecules into and out of, or through the cavity. Compartmentalization is enforced in nature by membranes or protein shells to consolidate functions and also defend sensitive operations or molecules from interruptions or damage, and it is of great scientific interest to create artificial nanostructures mimicking this capability. Technologies such as polymer or lipid vesicle technologies [89-91] fulfill this goal, but in comparison to DNA origami, neither are as programmable and addressable. On the other hand, DNA nanostructures are not continuous surface structures like a membrane is, and their parallel helices also have some fluctuation [48] that can reveal gaps in the structure. This can be improved using multiple layer DNA origami nanostructures $[24,25]$ such that the maximum gaps through a thick layer of helices are selectively impermeable to chosen molecules of the application. While not all applications of encapsulation are shapedependent, DNA nanostructures are uniquely capable of modulating the size of a cavity, the position or quantity of contained molecules, and access to the space as determined by DNA-based circuit logic.

\subsubsection{Nanocasting}

Control over shape and permeability has been vital to synthesizing shaped gold and silver nanoparticles using a hollowed DNA nanostructure as a mold via a process termed nanocasting [92,93] (Figure 6D). The nanocasting process utilizes seeded-growth nanoparticle synthesis but with the seed beginning within a shaped cavity that the growing nanoparticle will conform to. This process has been demonstrated with silica nanotubes [94] 
and protein shells [95] but without the same degree of shape variety as DNA nanostructures. The advantage of using DNA nanostructures to form the mold is the wide variety of shapes, such as cubes, discs, triangles, as well as their compositions, such as into Y-branch shapes. Expanding the available geometries of other technologies is, in isolation, already a significant research problem, while shape design via DNA origami is generalized across a variety of geometries. Currently, while still effective upon the shape of the metallic nanoparticle, the flexibility of DNA nanostructures slightly yields to the forces of nanoparticle growth upon its inner walls. Thus so far, the process mandates accurate timing, rather than fully relying on the walls of the DNA mold, to terminate nanoparticle growth, but methods as yet untested for nanocasting for improving the rigidity of DNA nanostructures could be later shown to improve nanocasting quality $[78,80]$. Nonetheless, the results show enticing potential for the bottom-up synthesis of plasmonic nanoparticles [92] or nanowires [96].

A

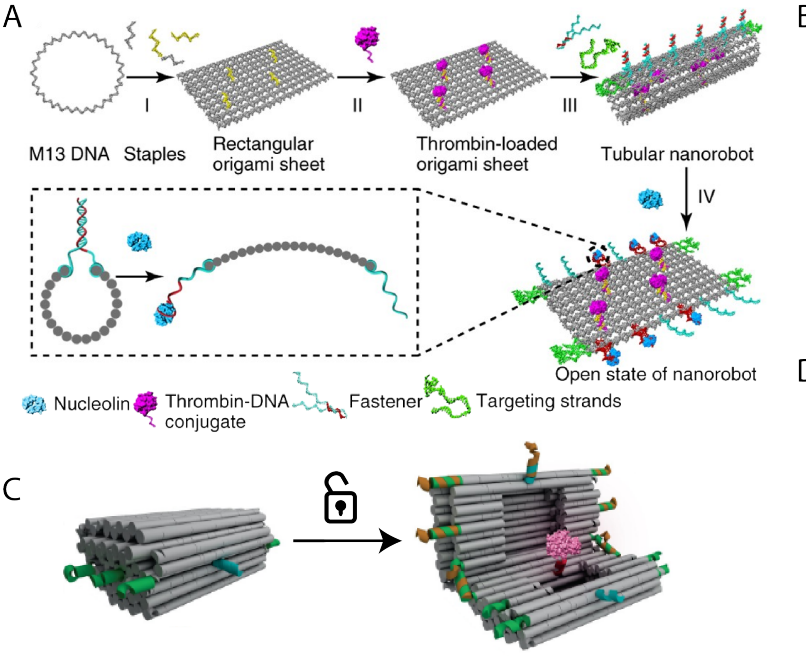

B

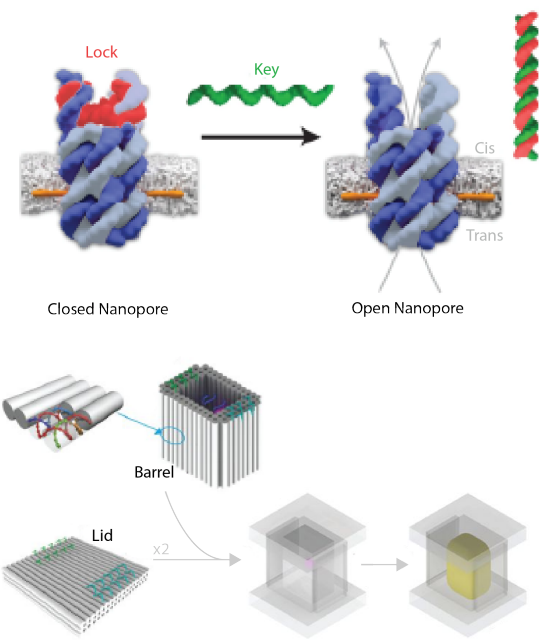

Figure 6. Applications of encapsulating DNA nanostructures. (A) A DNA nanorobot that selectively delivers thrombin to a tumor site to induce thrombosis of the tumor to destroy it (reprinted with permission from Springer Nature [97]); (B) A DNA nanopore with a locking mechanism that can restrict a flow of molecules through the channel (reprinted with permission from American Chemical Society [98]); (C) A DNA origami nanovault functions as a nanoreactor by capturing a single enzyme within its cavity and controlling its reactions via a latch mechanism (reprinted with permission from Springer Nature [99]); (D) A DNA origami mold that is used for nanocasting of gold nanoparticles (reprinted with permission from AAAS [92]).

\subsubsection{Single-Molecule Chemistry}

Nanoreactors are confinements of selected molecules such that there is some level of deliberate control over their reactions. Nanoreactors require the property of an impermeable encapsulation to be paramount in order to tailor environmental conditions for only specific reactions to occur and thus should be able to proficiently shield molecules from unfavorable reactants. The Andersen group demonstrated a DNA origami nanoreactor "vault" that could capture single enzymes within its cavity and could impose specific conditions on its locking mechanism [99] (Figure 6C) to further restrict reaction conditions. In doing so, the responsiveness of the enzyme to substrates can be reduced to desired situations in the interest of study or for inactivating unwanted pathways. Alternatively, enzymes can be spatially localized. This has been shown for 2D surfaces to measure the effect of distance separation on reactions and investigate biophysical mechanisms of target proteins [100,101], but also within the cavity of a DNA origami reactor [102-104]. This localization is similar to how natural enzymatic pathways achieve rapid reaction rates. Such a system will allow scientists to compose and study specific pathways under highly specific concentrations and relative distances. DNA nanostructures can also aid in isolating single membrane proteins by simulating a small lipid bilayer within a constructed cavity. 
Such studies are otherwise challenging due to the poor stability and activity of membrane proteins in any other environment than upon the cellular membrane [105], thus calling for strategies that can artificially simulate that environment.

\subsubsection{DNA-Based Drug Delivery Vehicles}

Drug delivery is an area where DNA nanostructures may inspire a new degree of complexity towards therapeutics. Targeted drug delivery is still an open challenge [106] that ideally establishes strategies for safe and successful delivery of a therapeutic payload by limiting their effective area to only diseased sites. This is especially a problem for drugs that must be circulated through the body to reach their intended site. The ability of DNA to easily load therapeutic molecules as cargo [107], as well as form structures and compute with biomolecular inputs [59] is a unique advantage of the material to satisfy this functionality. Placing such therapeutics within the cavity of a DNA nanostructure adds a layer of separation between the therapeutic and any other biomolecules it could damage. Then, DNA nanostructures can be designed to open and expose the cavity with its therapeutic payload when a targeted biomarker is observed by a programmed locking mechanism [59]. Current work still looks to establish the range of detectable biomarkers that can be transduced into DNA nanostructure activity, such as those that bind a protein biomarker with aptamers [97] or detect upregulated miRNA signals [108]. The limitation and future opportunities for research here, of course, are thus to expand the variety of biosensors that can be conjugated to DNA and incorporated into DNA nanostructures.

One area of high potential impact is the targeted delivery of anti-cancer drugs that can have severe side effects, such as doxorubicin which can cause damage to heart muscle. DNA circuits have been shown to perform complex profiling of cancer cells, thus heightening the specificity of any DNA nanostructure-based targeting for cancer therapeutics [109]. DNA nanostructure drug delivery vehicles have also been shown to remain sufficiently stable under in vivo conditions to passively build up at a tumor site [79]. Li et al. successfully delivered and released thrombin to tumors to induce thrombosis of the tumor only [97] (Figure 6A). Pan et al. demonstrated that DNA nanostructures can easily be programmed to carry multiple different drugs simultaneously, and could thus help the simultaneous delivery of multiple drug therapeutics to combat complex diseases that are drug-resistant [110].

\subsubsection{Membrane-Spanning DNA Nanopores}

DNA nanostructures have been used to build transmembrane channels, sometimes referred to as membrane-spanning DNA nanopores, that implant into a cellular membrane. Tubular DNA nanostructures decorated with hydrophobic groups along its outside enable a DNA nanostructure to embed itself into a lipid membrane as an artificial transmembrane channel $[111,112]$. We consider this an important function of encapsulation in isolating a leak-free channel for molecules to be transported across. Natural transmembrane channels span their lipid bilayer and typically help to regulate the nutrients within a cell. DNA nanopores may enable forced control over the nutrition gradient of cells by implementing commonly used locking mechanisms or could be used for biophysical studies of how materials pass through the membrane by monitoring voltage changes from the DNA nanopore that signal molecules passing through. The Howarka group demonstrated that designed DNA nanopores are functionally similar to their associated natural counterpart when measured for transport of $\mathrm{K}^{+}$ions [98] (Figure 6B). Proteins maybe also be passed through the channels and each event can be measured by the transduced electrical signal of the channel [113]. Gating can also be applied which blocks the channel under specifically programmed conditions to modulate the flow of molecules through the channel $[114,115]$.

\subsection{Surface Templating}

Surface templating is the principle of utilizing the geometry of DNA origami nanostructures to orient or position other molecules that do not have the intrinsic capability to 
organize to the geometric complexity of the DNA-based template. This most commonly entails using the addressable surface of a designed DNA nanostructure to specifically position guest molecules. While this can generally describe any application of DNA nanostructures interfacing with other molecules, we reserve this categorization for applications that do not have discerning features that would otherwise more appropriately describe them as encapsulating or exhibiting nanomechanical dynamism. In our proposed categorization, surface templating DNA nanostructures differ from those categorically identified with encapsulation functions by the fact that permeability is no longer an essential property of the DNA nanostructure itself. Although as with DNA-templated lipid nanostructures, the DNA nanostructure can still serve to template another material into an encapsulating structure. The first demonstrations of DNA origami included a world map of the Earth designed by attaching physical moieties to specifically addressed locations on the DNA origami surface, creating a pattern that could be imaged by AFM. This principle has since been exploited to arrange a widespread selection of other molecules. DNA nanostructures are addressable by binding functional groups, which can encompass organic or inorganic molecules, to nucleotides that are at the desired locations within the design. These modifications are usually done at the $5^{\prime}$ or $3^{\prime}$ end of a ssDNA segment, although there are situations that may call for modifications to be made mid-sequence as well, such as phosophorothioate for hydrocarbon modifications [116]. The ssDNA segment can be an extension of staple strands already included in the structural design of a DNA origami nanostructure or be a separate strand that hybridizes to a complementary domain extended from those strands. The latter option is typically chosen to be more economical and versatile as it decouples guest molecules from each unique staple sequence. For placement of the same guest molecule to multiple locations, a universal sequence can be used, which reduces costs, as functionalization can be an expensive process to repeat for many distinct strands. It is instead more economical to synthesize a universal complementary sequence extending from the staple strands. If multiple unique locations are desired, then the sequences can also be chosen with the necessary orthogonality. As such, DNA nanostructure surfaces can place guest molecules with a resolution similar to its own per base resolution of approximately $3.4 \AA$ along a strand or $2 \mathrm{~nm}$ between helices [117].

\subsubsection{Hybrid DNA-Lipid Nanostructures}

Lipid vesicles are lipid bilayer membranes typically encapsulating some fluid. Generally, cells and organelles all have such an encapsulating lipid bilayer membrane. Lipid vesicles that are artificially created are liposomes, which are self-assembled from amphiphilic lipid molecules. Liposomes preferably self-assemble into spherical shapes, but in natural systems, there also exist membrane proteins that can regulate the deformation of cellular membranes to consequently dictate cellular function. The function of these membranedeforming mechanisms still warrants study, and DNA nanostructures could help both probe and mimic their effects.

DNA nanostructures have been shown to template both the size and shape of lipid membranes. A DNA nanostructure template can be decorated with hydrophobic functional groups, usually lipid membrane components like cholesterol, but also hydrocarbon chains [116], that can embed into a lipid membrane. A lipid membrane self-assembles around the DNA nanostructure spanning the anchored hydrophobic groups [118], and this has been shown to manipulate continuous lipid membranes into unnatural configurations such as cuboids [119] or winding tubular configurations that have been also shown to mimic the structure of the golgi apparatus [120] (Figure 7B). The study of lipid vesicles is also made more challenging by inconsistencies of size and shape in leading synthesis techniques which still necessitate strict filtration of undesired specimens [121]. Round DNA barrels have been shown to act as a physical template for synthesizing lipid vesicles where it becomes energetically favorable for the lipid vesicle to conform to the size of DNA nanostructure template [122]. In biomimicry of nanodiscs [123], circular DNA templates can also consolidate a lipid bilayer for biophysical studies [116,124]. Another circular 
template, a DNA barrel extruded using hierarchical assembly, was also shown to be able to template the formation of a lipid membrane along the outer profile of the structure, forming a long, tubular lipid membrane [125].

A

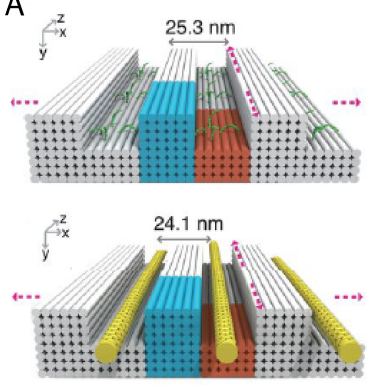

C
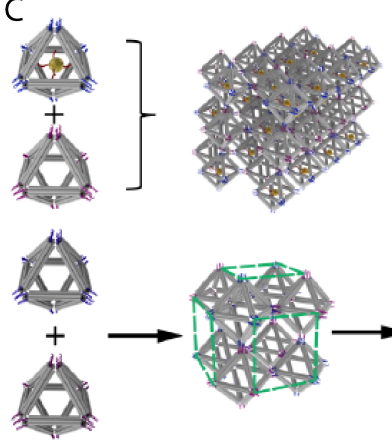

B

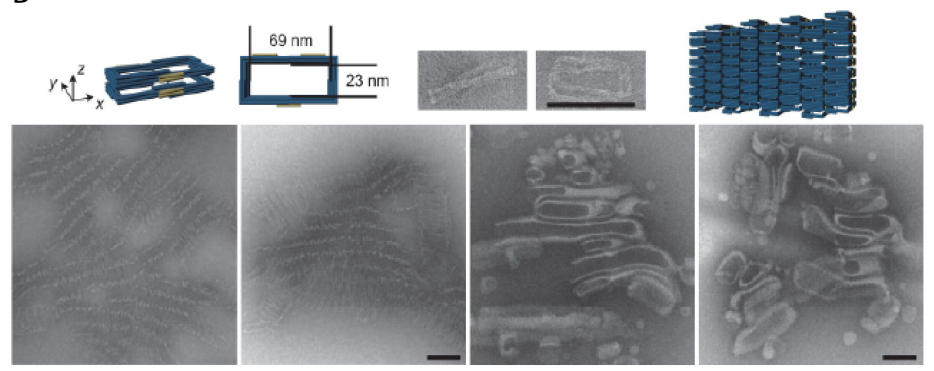

D

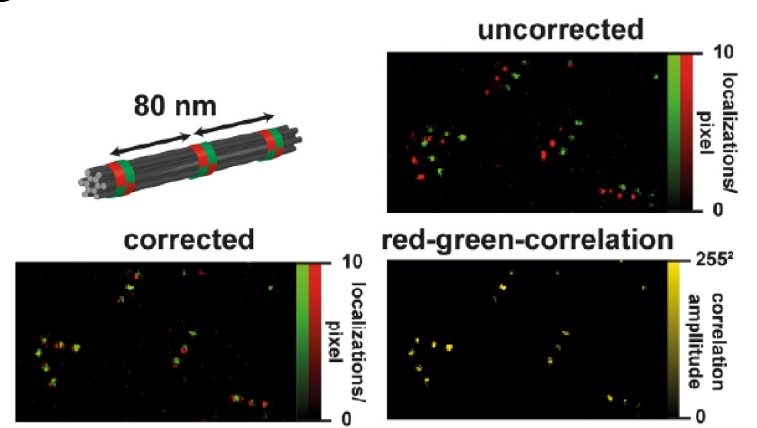

Figure 7. Applications of utilizing DNA nanostructures as a geometric template. (A) Pitch-scaling of carbon nanotubes by trenches constructed from DNA bricks (reprinted with permission from AAAS [126]); (B) Liposomes scaffolded by a DNA origami cage can replicate the appearance of the golgi apparatus (reprinted with permission from Springer Nature [120]); (C) Gold nanoparticles placed within polyhedral DNA nanostructures that assist in placing the gold nanoparticles in crystalline lattice positions (reprinted with permission from Springer Nature [44]); (D) A DNA origami bundle with tailored spacing of fluorophore markers that assist in the calibration of images against drift (reprinted with permission from Springer Nature [127]).

Biophysical studies of lipid membranes is also possible by using DNA nanostructures as an architectural framework. For example, joint work by the Lin and De Camilli groups used a DNA column as a ruler for spacing liposomes, which were themselves suspended in circular DNA origami templates at each end of the ruler. This provided insight into the transfer of lipids between lipid membranes [128]. Shaped DNA nanostructures can also be used to mechanically impose shape upon an existing membrane [129-131]. This is similar to the BAR-family of proteins, which have a role in forming tubular substructures in cells. For example, they may form filopodia, which are protrusions of the cell membrane that allow the cell to probe its environment. Composition and the organization of lipid membranes and their membrane proteins can also be studied by tracking DNA barges that have targeted specific behavior or interactions upon the membrane surface $[132,133]$. These studies help to show how DNA origami can elucidate the mechanical properties of cellular function. For further reading, interactions of DNA nanostructures with membrane surfaces has also recently been thoroughly reviewed [134].

\subsubsection{Molecular-Scale Imaging with DNA Nanostructures}

The consistent and specific shape of DNA nanostructures make it a dependable reference object to assist in the characterization of other nanoscale moieties. Given the rise of techniques like super-resolution microscopy, it is now possible to observe specimens with nanometer resolution, but to exactly quantify spatial information solicits the development of a consistent frame of reference. Here, the geometry, including the size, length, and 
sometimes even aspect ratio, and stability of DNA nanostructures offers a consistent, widely compatible metric to measure by.

Martin et al. used a DNA origami nanostructure with a hollow column to facilitate tomography measurements by suspending a desired analyte in the cavity [135]. The aspect ratio of the supporting DNA nanostructure determines its orientation within a film of vitreous ice, while the structure can also protect the analyte from harmful interactions with surrounding molecules or with the air-water interface. The shape of the supporting DNA nanostructure provides an orientation reference, and the binding of an analyte to the DNA suspension wire can also tilt the orientation of the sample itself. The shape variety of DNA nanostructures can also be used to resolve difficult properties, such as single nucleotide polymorphisms, instead by shape [136] or alternatively by barcoding the surface with physical protrusions [137], then imaging with AFM. The consistent and predictable shape of DNA nanostructures can also be used as calibration or measurement references. Designed lengths of DNA origami nanostructures can provide an object of known size to perform in situ calibration for AFM analyses [138]. Straight DNA nanostructures of fixed length can most importantly be reproducibly synthesized in high yield. This is especially helpful to the communication of data, where instead of nanoscale standards needing to travel and risk damage, they can be communicated via the saved design of the DNA nanostructure. In several examples, fluorophores can be placed at exact locations with known spacing distances along its addressable surface to provide a reproducible nanoruler $[139,140]$. For example, Raab et al. use a DNA origami bundle with red and green fluorophores to calibrate against drift [127] (Figure 7D).

\subsubsection{Nanofabrication of Plasmonic and Nanoelectric Devices}

There are numerous strategies for DNA nanostructure templates to bind or interact with inorganic nanomaterials such as gold or carbon nanotubes. Thiol-modified DNA strands are a well-known method for conjugating gold nanoparticles to DNA nanostructures, but so can various peptides and proteins [141]. The geometry of a DNA nanostructure template can provide an unparalleled substrate to pursue the bottom-up assembly of electric and plasmonic nanodevices. Studies involving DNA-templated gold clusters have been numerous in the last decade, but recent work has also drawn attention to a wider variety of inorganic materials such as silica and carbon nanotubes. Considering the breadth of proteins and peptides with specific material affinities that have yet to be used in conjunction with DNA nanostructures, a major paradigm shift in the possible applications of DNA nanostructure templates for nanofabrication could linger in the near future.

DNA-templated arrangements of metallic nanoparticles have been a major research focus for realizing a bevy of novel plasmonic nanodevices and phenomena in the last two decades. Some of the earliest demonstrations were with single DNA duplexes acting as tethers to assist the ordered aggregation of gold nanoparticles $[142,143]$. Since then, many new techniques have been developed implementing complex geometric arrangements. The intensity and wavelength of plasmonic phenomena is heavily dependent on the geometric arrangement and composition of its metallic components, such as gold, silver, and platinum. In single particles, the geometry is typically constrained by the extent to which crystallographic facets of the material can be chemically restricted for growth beginning from a seed. While this has generated an incredible variety of particles, including spheres, rods, triangles, and stars, arranging them for reproducible cluster or colloidal effects has been much more challenging.

Many applications have since demonstrated the advantages of tailored shape design using DNA nanostructures in comparison to existing biological templates such as viral capsids or bacterial scaffolds $[141,144,145]$. Chiral assemblies of gold nanospheres spaced helically along a straight DNA origami bundle emit a distinct circular dichroism signal [146]. Similar effects are also generated by gold nanorods oriented along the edges of an adjoining pair of DNA origami triangles [147], and in general, there have been numerous methods to produce chiral orientations using a DNA nanostructure support [148-154]. Nanoparticle 
geometry can also determine field enhancement effects. For example, gold nanospheres arranged into a square on a flat DNA origami template form a SERS hotspot in the negative space in their middle [155]. The Ding group and collaborators used a DNA origami template to position two gold triangles with nanometer precision in a bowtie shape to generate a high local field enhancement between their tips [156]. The Ke group and collaborators created DNA nanotubes from a honeycomb lattice similar to how carbon nanotubes appear as rolled sheets of graphene, then set gold nanoparticles into specific lattice holes as a strategy for producing plasmonic metamaterials [157]. Recent work by Tinnefeld and collaborators demonstrated a construction of a DNA nanoantenna to facilitate detection for bioassays, especially when expensive, highly sensitive detectors are unavailable. Two silver nanoparticles were set across from each other around a DNA bundle. This placement created a plasmonic hotspot within the small gap between the nanoparticles, and the DNA nanoantenna was designed with a small reservoir for capturing analytes that was positioned within this gap such that the fluorescence-labelled signal from detection events would be amplified [158].

Over time, the scale of DNA-templated nanoparticle assemblies has also become increasingly complex by utilizing the modular assembly of DNA nanostructures into multicomponent, superstructure assemblies. Zhu et al. reported a modular strategy in which, first, gold nanoparticles are placed anywhere within a half-hexagonal DNA origami trough, then those troughs, each as a module, could be linked in series to form a specific, linear assembly of gold nanoparticles [159]. The Gang group demonstrated a strategy for utilizing polyhedral DNA origami as a frame for fabricating gold nanoparticle clusters with high spatial complexity. Attachment of gold nanoparticles on selected vertex points of the polyhedral DNA frame produced specific geometric arrangements of gold nanoparticles that can mimic the position of atoms in a crystal lattice unit cell. This could be done either using a single, high-degree polyhedra [160] or a large, crystalline assembly of low-degree polyhedra such as cubes and octahedrons, where gold nanoparticles could be placed at either the vertices or at the center of the structure [44,161,162] (Figure 7C). The Turberfield group demonstrated a deterministic strategy of tethering gold nanoparticles using DNA origami nanoflowers, which wrap around a gold nanoparticle giving it rotational specificity [163].

DNA-assisted fabrication of electronic nanodevices has also garnered significant research attention. Carbon nanotubes (CNTs) have been an enticing candidate to outperform and replace silicon-based electronics. However, they are difficult to individually handle and align to precisely tailor the electrical properties of any CNT connection. Sun et al. used micrometer-scale trench-like structures constructed by DNA bricks as a solution to the challenging problem of aligning and positioning CNTs between two nodes [126] (Figure 7A). DNA strands attached to the CNTs guided and locked them into parallel trenches that were only wide enough for a single CNT, thereby physically filtering and aligning them. The Sun group also later used this technique to create FET transistors [164]. Site-specific growth of metallic nanostructures based on a DNA nanostructure template have also been explored via different metallic growth strategies. Bayrak et al. used the nanocasting strategy to create gold nanowires by growing a gold crystal through a chain of DNA origami molds [96]. Jia et al. demonstrated how low-valence metal ions $\left(\mathrm{Cu}^{2+}\right.$ and $\left.\mathrm{Ag}^{2+}\right)$ aggregate to and begin to metallize upon clusters of long ssDNA preferentially over stiffer DNA origami as a seedless approach to the fabrication of metallic nanostructures [165]. Shen et al. used DNA origami nanostructures as a lithography mask to produce similarly shaped patterns of gold upon a silicon nitride chip [166] to create plasmonic nanostructures.

\subsection{DNA Nanomechanics}

DNA nanomechanics focus on design principles of DNA nanostructures that enable dynamic, physical motion for interacting with the nanoscale. Kinesin is a natural example of a natural dynamic system for transporting biomolecular cargo along microtubule tracks [167]. The 2016 Nobel prize in chemistry was awarded in recognition of the progress in artificial 
nanomachine development, specifically rotaxanes and catananes [168-170]. Within the field of DNA nanotechnology, the range of motion possible with DNA nanostructures has rapidly caught up with its counterparts. DNA walkers are a close mimicry of kinesin, while rotational and linear motion have also been established [53,54,72,171]. Moreover, the versatility of building with DNA benefits from parallel research on its conjugation with other materials, its stability and safety, and signal processing capabilities whereas challenging, novel work would otherwise be necessary for other substrates. As stated previously, the operation of DNA nanomechanics strongly depends on techniques for consolidating triggers to simple inputs. These techniques are important to ensure that the physical configuration of a DNA nanostructure responds to the presence of DNA inputs or other molecules that bond to receptor sites upon a DNA origami. Shapes and their transitions can then be exploited for physical or optical readout. Provided that the configuration of a nanomechanical system is controllable by consolidated modules of short duplexes, then it becomes straightforward to add, remove, or modulate the length of those strands, typically by strand displacement.

\subsubsection{Tunable Plasmonics}

As plasmonic signals are dependent on the geometry of their metallic components, dynamic DNA nanostructures can switch between different modes of plasmonic signals. This enables optical readout of targeted events and also provides a single device that could generate an optical profile of multiple targets by responsively changing their geometry in response to their tagged target. Zhan et al. demonstrated this principle using a DNA origami tripod structure, where each leg was decorated with a gold nanorod [152] (Figure 8C). Struts, which were comprised of two DNA duplexes, spanned each pair of legs. The tripod legs could be adjusted between angles of $30^{\circ}, 60^{\circ}$, and $90^{\circ}$, which changed the plasmonic response of the structure. Huang et al. designed a system using two straight DNA origami bundles arranged in a four-arm junction that rotate with respect to a center point. By attaching gold nanorods to each bundle, a circular dichroism signal could be generated. ssDNA along each bundle could be selectively hybridized when provided corresponding oligonucleotide input strands, which would then set the respective angle of the rods to modulate changes in the signal [148].

A

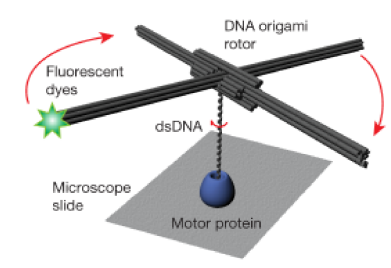

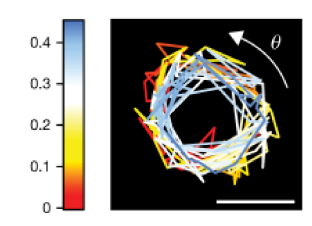

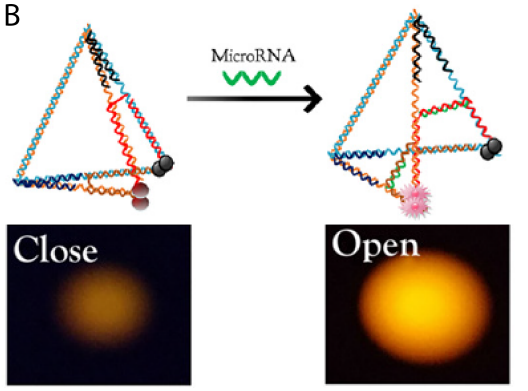

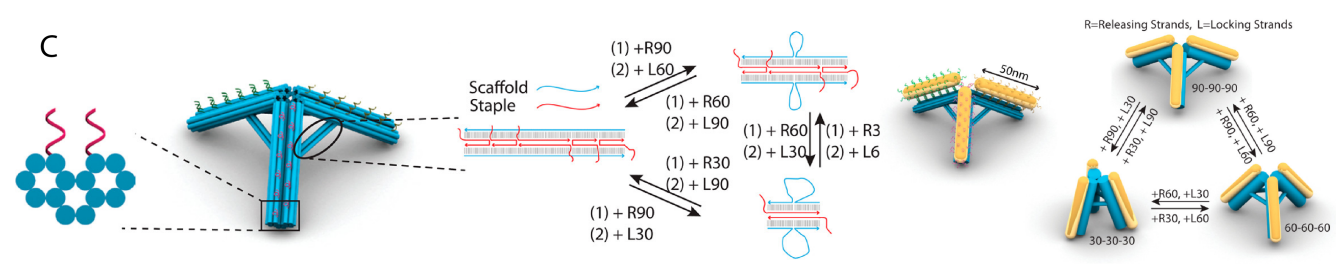

Figure 8. Applications of DNA nanomechanics. (A) A rotating DNA origami nanostructure with a fluorophore attached on the tip to track the activity of DNA rotation from genome-processing motor proteins (reprinted with permission from Springer Nature [171]); (B) A DNA tetrahedron that undergoes a physical change to generate a FRET-based signal in response to detecting an mRNA biomarker (reprinted with permission from AAAS [172]); (C) A tripod DNA nanostructure that can reconfigure the angles of its legs by swapping out ssDNA modules within the struts that span adjacent legs (reprinted with permission from American Chemical Society [152]). 


\subsubsection{Biosensing}

Rather than amplifying low concentration signals, DNA nanomechanical devices may provide an alternative, physical indicator for an analyte. Binding events permanently alter the physical configuration of the DNA nanostructure which serves to transduce the chemical input into a physical signal that can be readout with less sensitive microscopy techniques. One such device is a scissor-like DNA origami nanostructure with receptor strands on both sides of the resemblant blade edge. An analyte triggers hybridization between these two receptor strands and causes the scissors to close, and this new configuration can then be characterized by AFM [173]. Tetrahedron DNA nanostructures have been used to detect intracellular microRNA in a very characteristic demonstration of the core concepts of a nanomechanical DNA device. A FRET pair was placed at two vertices of the tetrahedron, while a ssDNA region spanned the edges as a probe. The length of the probe sequence was shorter than the analyte sequence, such that when the microRNA analyte was bound, it would also displace a bit more of the ssDNA endpoints that were hybridized into the edges of the triangular face. This would lengthen the spanning duplex between the edges and consequently increase the spacing between the FRET pair, providing an optical readout of the analyte being detected [172] (Figure 8B). Koiral et al. demonstrated a extension and contraction of a chain of 2D DNA origami rectangles, where adjacent structures were linked by two points, a fixed hinge and a duplex latch. Undoing latches caused the chain to unravel and lengthen, and this change could then be imaged by physically characterizing the structure [174].

\subsubsection{Biophysical Studies}

DNA nanomechanics can also be used to study biophysical processes. Since the material properties of DNA are well-understood, their physical deformation can be easily converted into values of force and energy. For instance, a hinged DNA nanostructure allowed Funke et al. to measure the attractive forces between two nucleosomes [175]. A hinged DNA nanostructure was designed to have a preferred open configuration. A pair of nucleosomes were then placed on the top and bottom platforms, and their attractive force would work against the tension of the hinge, reducing its angle. This new angle could be observed under transmission force microscopy or by a transduced FRET signal, and the attractive force between the nucleosomes could be calculated from the known values required to produce the measured displacement of the DNA nanostructure. Kosuri et al. designed a DNA origami nanostructure resembling helicopter blades which was used to characterize genome-processing reactions that generate DNA rotation [171] (Figure 8A). A fluorophore attached to the end of one blade could be optically tracked over time to reconstruct the sequence of biochemical events. Zhu et al. engineered a DNA tetrahedron into a nanoscale pump, showing that dynamic DNA nanostructures could induce physical changes into its environment, rather than only measure them. In reaction to $\mathrm{pH}$ changes, an i-motif sequence in one edge of the tetrahedron causes the structure to collapse, creating a downwards piston pumping motion, and reversing the $\mathrm{pH}$ conditions could straighten the edge again to push the piston upwards. It was shown that this DNA nanodevice could pump water and ferricynide [176].

Constructions of DNA origami nanosprings, which are DNA origami bundles with consistent negative superhelical strain causing the bundle to coil, have been shown to measure and exert forces. Karna et al. used i-motifs to implement $\mathrm{pH}$-dependent coiling, which could then be modulated to exert piconewton forces. Integrin-binding peptide domain RGD (arginyl-glycyl-aspartic acid acid) regularly placed along the nanospring could transduce $\mathrm{pH}$ control into clustering and declustering of cell surface integrin, which in turn controls membrane deformations that occur for cell motion [177]. Iwaki et al. used a DNA nanospring to instead measure the mechanical forces of myosin IV, which can function as a vesicle transporter along actin filamet pathways. A DNA nanospring was attached between anchored and active myosin IV and labelled with fluorosphores to measure any displacement. The rigidity of DNA nanostructures ensured that determined 
mechanical properties of the DNA nanospring, such as its spring constant, would be consistent, which would be sufficient to deduce the forces applied as evaluated from the observed displacement of the nanospring [178].

\subsection{Challenges $\mathcal{E}$ Future Perspectives}

The economics of DNA nanostructures is unfavorable as long as it is a strategy that depends on the custom synthesis of hundreds of distinct oligonucleotides. It is unlikely that structural DNA nanotechnology will ever be decoupled from the cost of oligonucleotide synthesis. There are enzymatic and bacteriophage toolkits $[179,180]$ that may lower costs, but this trend is counteracted by the ambition of continuing to pursue larger and more complex DNA nanostructures. However, as argued by Coleridge and Dunn [181], this may not be prohibitive at all. Instead, the challenges facing widespread adoption of DNA nanomachines are technical, regulatory, and ethical. No other biomaterial thus far discovered has such ubiquitous functionality as DNA, and as such, it is doubtful that it would not have some role in designing future therapeutics to be safe, smart, and multifunctional. DNA is unlikely to provoke concerning immunological effects, or there will be sufficient techniques to ensure that $[35,83]$, but for the time being, there is insufficient evidence to guarantee that inclination beyond all doubt, and DNA nanostructures are likely still far away from even entering any clinical trials.

Positive progress is still ongoing in regards to the size, complexity, synthesis, and design strategies for 3D DNA nanostructures. There is wide support, interest, and efforts in addressing their stability across a broad range of environments and increasing their list of compatibilities with chemical or biomolecule targets. However, more practical usage may beckon that the responsivity of operating DNA nanomachines is improved. DNA nanodevices lack reliable and rapid methods of signal transduction and real-time communication into and out of nanomechanical DNA systems, even the fastest still on the timescale of minutes or hours; this in part due to the intrinsic limits of reaction speeds or challenges with measuring DNA nanodevices with high resolution via fluorescence due to the scale of DNA nanodevices falling under diffraction limits. Further examples of the application of physical forces by DNA nanomachines are a pressing and interesting new research direction. While there are demonstrations of the enforcement of rigid shape [92,129], measurements of physical forces [175,178], transport of molecules by DNA nanodevices [182], examples of dynamic nanomechanical DNA devices applying physical forces have only recently appeared [177]. There are still yet many possible architectures for applying piconewton forces to explore $[61,183]$. On the scale of microrobots, the capability to self-propel and autonomously navigate fluidic environments has been a phenomenal development, but there does not seem to be a path of development there for DNA nanomachines, which may always require a nanotrack. There are recent demonstrations of DNA walkers operating in vivo which indicates a hopeful trend [184]. Design of DNA nanostructures and their functions have also proceeded in a vacuum, where scientists have attempted to accomplish almost everything with only DNA. It will be interesting to see the progress of future devices that are interdependently integrated with natural mechanisms, such as the diffusion of membrane proteins upon a cell membrane [185], borrowing the function of natural motors like kinesin and driving nanomechanical motion with ATP rather than DNA springs [186], or relying on or reinforcing other structures, such as viral capsids or liposomes, while providing functionality that DNA is advantaged in like computing or actuation.

Some of these directions are naturally limited by DNA as a material, that while they can be accomplished may not surpass competing technologies, as properties such as bond strength and reaction rate are built into the material such that to change them would mean to change the chemical makeup of the material itself. This could be a potential long-term future of DNA nanotechnology, that is, to apply the concepts to an artificial material that behaves and self-assembles like, but is no longer, DNA. Or, due to its wide compatibility and versatility, DNA nanostructures could supplement and patch the shortcomings of other materials, that is, the future of DNA nanostructures may no longer be as monolithic 
structures, but smoothly integrated into heterogeneous superstructures comprised of multiple materials to compensate for shortfalls in each material. Nonetheless, the field is still rapidly growing and continually attracting interdisciplinary attention, as potential benefits of DNA nanoscience appear to span an enormous breadth of disciplines. This is a positive sign, as the coalescence of distant fields of science are excellent grounds for innovation.

\section{Conclusions}

In observing the current progress in the field, one may have a sense that evolution and technology have come full circle. We can now pull upon the vast knowledge of humanengineered architectures as an inspiration for nanomachines that will work alongside the same natural machines that make and inspired us. In our discussion of such progress, we framed potential applications of DNA nanostructures into three archetypal categories where shaped and dynamic nanostructures have demonstrated a clear capacity for satisfying specific mechanical functions. DNA nanostructures can construct protective casings, scaffold the construction of other materials such as lipids and metals, and replicate a variety of basic mechanisms such as latches, hinges, joints, pivots, rotary and sliding gears, tweezers, and rotors. There is now a well-established foundation of DNA nanostructure design strategies for mimicking nearly any shape and mechanism imaginable. Novel methods for actuating these components are also being developed at a rapid pace. Chemistry established for the linkage of DNA to other materials has been thoroughly integrated into monolithic DNA nanostructures yielding many hybrid structures that may yet expand the field of mechanical tuning possible for custom-made nanostructures. The field now focuses its attention applying a well-defined toolbox into applications where traditional chemical, lithography, or optical methods have started to face limitations in their resolution, shape, or ability to implement complex control systems and dynamic mechanisms. By only changing its shape, DNA nanostructures have spanned fields of medicine, biosensing, nanofabrication, plasmonics, single-molecule chemistry, and facilitating biophysical studies. Ongoing studies on the stability, safety, and improvements to current shape-based phenomena, such as signal transduction and rate of operation, will further improve the practicality of DNA nanostructures in interdisciplinary applications. Even if DNA itself as the core material may become obsolete, the tenets of DNA-based self-assembly will undoubtedly carry forward to curate a full paradigm shift into broad and interactive access to the nanoscale.

Author Contributions: D.F. and J.R.; writing—original draft preparation, D.F.; writing-review and editing, D.F. and J.R.; funding acquisition, J.R. All authors have read and agreed to the published version of the manuscript.

Funding: This work was funded by NSF granted number CCF-1909848.

Institutional Review Board Statement: Not applicable.

Informed Consent Statement: Not applicable.

Data Availability Statement: Not applicable.

Conflicts of Interest: The authors declare no conflict of interest.

\section{References}

1. Schmick, M.; Bastiaens, P.I. The interdependence of membrane shape and cellular signal processing. Cell 2014, 156, 1132-1138. [CrossRef] [PubMed]

2. Van de Waterbeemd, H.; Camenisch, G.; Folkers, G.; Chretien, J.R.; Raevsky, O.A. Estimation of blood-brain barrier crossing of drugs using molecular size and shape, and H-bonding descriptors. J. Drug Target. 1998, 6, 151-165. [CrossRef] [PubMed]

3. Reinhart, W.H.; Chien, S. Red cell rheology in stomatocyte-echinocyte transformation: Roles of cell geometry and cell shape. Blood 1986, 67, 1110-1118. [CrossRef]

4. Guo, P. The emerging field of RNA nanotechnology. Nat. Nanotechnol. 2010, 5, 833. [CrossRef] 
5. Gonen, S.; DiMaio, F.; Gonen, T.; Baker, D. Design of ordered two-dimensional arrays mediated by noncovalent protein-protein interfaces. Science 2015, 348, 1365-1368. [CrossRef] [PubMed]

6. Ljubetič, A.; Lapenta, F.; Gradišar, H.; Drobnak, I.; Aupič, J.; Strmšek, Ž.; Lainšček, D.; Hafner-Bratkovič, I.; Majerle, A.; Krivec, N.; et al. Design of coiled-coil protein-origami cages that self-assemble in vitro and in vivo. Nat. Biotechnol. 2017, 35, 1094. [CrossRef] [PubMed]

7. Andersen, E.S.; Dong, M.; Nielsen, M.M.; Jahn, K.; Subramani, R.; Mamdouh, W.; Golas, M.M.; Sander, B.; Stark, H.; Oliveira, C.L.; et al. Self-assembly of a nanoscale DNA box with a controllable lid. Nature 2009, 459, 73-76. [CrossRef]

8. Douglas, S.M.; Dietz, H.; Liedl, T.; Högberg, B.; Graf, F.; Shih, W.M. Self-assembly of DNA into nanoscale three-dimensional shapes. Nature 2009, 459, 414. [CrossRef] [PubMed]

9. Dietz, H.; Douglas, S.M.; Shih, W.M. Folding DNA into twisted and curved nanoscale shapes. Science 2009, 325, 725-730. [CrossRef] [PubMed]

10. Han, D.; Pal, S.; Nangreave, J.; Deng, Z.; Liu, Y.; Yan, H. DNA origami with complex curvatures in three-dimensional space. Science 2011, 332, 342-346. [CrossRef] [PubMed]

11. Han, D.; Pal, S.; Yang, Y.; Jiang, S.; Nangreave, J.; Liu, Y.; Yan, H. DNA gridiron nanostructures based on four-arm junctions. Science 2013, 339, 1412-1415. [CrossRef] [PubMed]

12. Benson, E.; Mohammed, A.; Gardell, J.; Masich, S.; Czeizler, E.; Orponen, P.; Högberg, B. DNA rendering of polyhedral meshes at the nanoscale. Nature 2015, 523, 441. [CrossRef] [PubMed]

13. Veneziano, R.; Ratanalert, S.; Zhang, K.; Zhang, F.; Yan, H.; Chiu, W.; Bathe, M. Designer nanoscale DNA assemblies programmed from the top down. Science 2016, 352, 1534. [CrossRef] [PubMed]

14. Zhang, F.; Jiang, S.; Wu, S.; Li, Y.; Mao, C.; Liu, Y.; Yan, H. Complex wireframe DNA origami nanostructures with multi-arm junction vertices. Nat. Nanotechnol. 2015, 10, 779. [CrossRef]

15. Iinuma, R.; Ke, Y.; Jungmann, R.; Schlichthaerle, T.; Woehrstein, J.B.; Yin, P. Polyhedra self-assembled from DNA tripods and characterized with 3D DNA-PAINT. Science 2014, 344, 65-69. [CrossRef]

16. Ong, L.L.; Hanikel, N.; Yaghi, O.K.; Grun, C.; Strauss, M.T.; Bron, P.; Lai-Kee-Him, J.; Schueder, F.; Wang, B.; Wang, P.; et al. Programmable self-assembly of three-dimensional nanostructures from 10,000 unique components. Nature 2017, 552, 72. [CrossRef]

17. Seeman, N.C. Nucleic acid junctions and lattices. J. Theor. Biol. 1982, 99, 237-247. [CrossRef]

18. Chen, J.; Seeman, N.C. Synthesis from DNA of a molecule with the connectivity of a cube. Nature 1991, 350, 631-633. [CrossRef]

19. Winfree, E.; Liu, F.; Wenzler, L.A.; Seeman, N.C. Design and self-assembly of two-dimensional DNA crystals. Nature 1998, 394, 539-544. [CrossRef]

20. Paukstelis, P.J.; Nowakowski, J.; Birktoft, J.J.; Seeman, N.C. Crystal structure of a continuous three-dimensional DNA lattice. Chem. Biol. 2004, 11, 1119-1126. [CrossRef]

21. Zheng, J.; Birktoft, J.J.; Chen, Y.; Wang, T.; Sha, R.; Constantinou, P.E.; Ginell, S.L.; Mao, C.; Seeman, N.C. From molecular to macroscopic via the rational design of a self-assembled 3D DNA crystal. Nature 2009, 461, 74-77. [CrossRef]

22. Rothemund, P.W.; Papadakis, N.; Winfree, E. Algorithmic self-assembly of DNA Sierpinski triangles. PLoS Biol. 2004, 2, e424. [CrossRef] [PubMed]

23. Rothemund, P.W. Folding DNA to create nanoscale shapes and patterns. Nature 2006, 440, 297. [CrossRef] [PubMed]

24. Ke, Y.; Douglas, S.M.; Liu, M.; Sharma, J.; Cheng, A.; Leung, A.; Liu, Y.; Shih, W.M.; Yan, H. Multilayer DNA origami packed on a square lattice. J. Am. Chem. Soc. 2009, 131, 15903-15908. [CrossRef] [PubMed]

25. Ke, Y.; Voigt, N.V.; Gothelf, K.V.; Shih, W.M. Multilayer DNA origami packed on hexagonal and hybrid lattices. J. Am. Chem. Soc. 2012, 134, 1770-1774. [CrossRef] [PubMed]

26. Kuzuya, A.; Komiyama, M. Design and construction of a box-shaped 3D-DNA origami. Chem. Commun. 2009, $28,4182-4184$. [CrossRef] [PubMed]

27. Ke, Y.; Sharma, J.; Liu, M.; Jahn, K.; Liu, Y.; Yan, H. Scaffolded DNA origami of a DNA tetrahedron molecular container. Nano Lett. 2009, 9, 2445-2447. [CrossRef]

28. Han, D.; Pal, S.; Liu, Y.; Yan, H. Folding and cutting DNA into reconfigurable topological nanostructures. Nat. Nanotechnol. 2010, 5, 712-717. [CrossRef]

29. Liedl, T.; Högberg, B.; Tytell, J.; Ingber, D.E.; Shih, W.M. Self-assembly of three-dimensional prestressed tensegrity structures from DNA. Nat. Nanotechnol. 2010, 5, 520-524. [CrossRef]

30. Douglas, S.M.; Marblestone, A.H.; Teerapittayanon, S.; Vazquez, A.; Church, G.M.; Shih, W.M. Rapid prototyping of 3D DNA-origami shapes with caDNAno. Nucleic Acids Res. 2009, 37, 5001-5006. [CrossRef]

31. Williams, S.; Lund, K.; Lin, C.; Wonka, P.; Lindsay, S.; Yan, H. Tiamat: A three-dimensional editing tool for complex DNA structures. In International Workshop on DNA-Based Computers; Springer: Berlin/Heidelberg, Germany, 2008 ; pp. 90-101.

32. Jun, H.; Shepherd, T.R.; Zhang, K.; Bricker, W.P.; Li, S.; Chiu, W.; Bathe, M. Automated sequence design of 3D polyhedral wireframe DNA origami with honeycomb edges. ACS Nano 2019, 13, 2083-2093. [CrossRef]

33. Jun, H.; Zhang, F.; Shepherd, T.; Ratanalert, S.; Qi, X.; Yan, H.; Bathe, M. Autonomously designed free-form 2D DNA origami. Sci. Adv. 2019, 5, eaav0655. [CrossRef] [PubMed]

34. Ke, Y.; Ong, L.L.; Shih, W.M.; Yin, P. Three-dimensional structures self-assembled from DNA bricks. Science 2012, 338, 1177-1183. [CrossRef] [PubMed] 
35. Engelhardt, F.A.; Praetorius, F.; Wachauf, C.H.; Brüggenthies, G.; Kohler, F.; Kick, B.; Kadletz, K.L.; Pham, P.N.; Behler, K.L.; Gerling, T.; et al. Custom-size, functional, and durable DNA origami with design-specific scaffolds. ACS Nano 2019, 13, 5015-5027. [CrossRef]

36. Kick, B.; Praetorius, F.; Dietz, H.; Weuster-Botz, D. Efficient production of single-stranded phage DNA as scaffolds for DNA origami. Nano Lett. 2015, 15, 4672-4676. [CrossRef]

37. Marchi, A.N.; Saaem, I.; Vogen, B.N.; Brown, S.; LaBean, T.H. Toward larger DNA origami. Nano Lett. 2014, 14, 5740-5747. [CrossRef] [PubMed]

38. Bush, J.; Singh, S.; Vargas, M.; Oktay, E.; Hu, C.H.; Veneziano, R. Synthesis of DNA Origami Scaffolds: Current and Emerging Strategies. Molecules 2020, 25, 3386. [CrossRef] [PubMed]

39. Wagenbauer, K.F.; Sigl, C.; Dietz, H. Gigadalton-scale shape-programmable DNA assemblies. Nature 2017, 552, 78-83. [CrossRef]

40. Chandran, H.; Gopalkrishnan, N.; Yurke, B.; Reif, J. Meta-DNA: Synthetic biology via DNA nanostructures and hybridization reactions. J. R. Soc. Interface 2012, 9, 1637-1653. [CrossRef]

41. Yao, G.; Zhang, F.; Wang, F.; Peng, T.; Liu, H.; Poppleton, E.; Šulc, P.; Jiang, S.; Liu, L.; Gong, C.; et al. Meta-DNA structures. Nat. Chem. 2020, 12, 1067-1075. [CrossRef] [PubMed]

42. Gerling, T.; Wagenbauer, K.F.; Neuner, A.M.; Dietz, H. Dynamic DNA devices and assemblies formed by shape-complementary, non-base pairing 3D components. Science 2015, 347, 1446-1452. [CrossRef]

43. Zhang, T.; Hartl, C.; Frank, K.; Heuer-Jungemann, A.; Fischer, S.; Nickels, P.C.; Nickel, B.; Liedl, T. 3D DNA origami crystals. Adv. Mater. 2018, 30, 1800273. [CrossRef]

44. Tian, Y.; Lhermitte, J.R.; Bai, L.; Vo, T.; Xin, H.L.; Li, H.; Li, R.; Fukuto, M.; Yager, K.G.; Kahn, J.S.; et al. Ordered three-dimensional nanomaterials using DNA-prescribed and valence-controlled material voxels. Nat. Mater. 2020, 19, 789-796. [CrossRef] [PubMed]

45. Kim, D.N.; Kilchherr, F.; Dietz, H.; Bathe, M. Quantitative prediction of 3D solution shape and flexibility of nucleic acid nanostructures. Nucleic Acids Res. 2011, 40, 2862-2868. [CrossRef]

46. Snodin, B.E.; Randisi, F.; Mosayebi, M.; Šulc, P.; Schreck, J.S.; Romano, F.; Ouldridge, T.E.; Tsukanov, R.; Nir, E.; Louis, A.A.; et al. Introducing improved structural properties and salt dependence into a coarse-grained model of DNA. J. Chem. Phys. 2015, 142,06B613_1. [CrossRef]

47. Maffeo, C.; Yoo, J.; Aksimentiev, A. De novo reconstruction of DNA origami structures through atomistic molecular dynamics simulation. Nucleic Acids Res. 2016, 44, 3013-3019. [CrossRef] [PubMed]

48. Snodin, B.E.; Schreck, J.S.; Romano, F.; Louis, A.A.; Doye, J.P. Coarse-grained modelling of the structural properties of DNA origami. Nucleic Acids Res. 2019, 47, 1585-1597. [CrossRef] [PubMed]

49. Doye, J.P.; Fowler, H.; Prešern, D.; Bohlin, J.; Rovigatti, L.; Romano, F.; Šulc, P.; Wong, C.K.; Louis, A.A.; Schreck, J.S.; et al. The oxDNA coarse-grained model as a tool to simulate DNA origami. arXiv 2020, arXiv:2004.05052.

50. Yoo, J.; Aksimentiev, A. In situ structure and dynamics of DNA origami determined through molecular dynamics simulations. Proc. Natl. Acad. Sci. USA 2013, 110, 20099-20104. [CrossRef]

51. Kube, M.; Kohler, F.; Feigl, E.; Nagel-Yüksel, B.; Willner, E.M.; Funke, J.J.; Gerling, T.; Stömmer, P.; Honemann, M.N.; Martin, T.G.; et al. Revealing the structures of megadalton-scale DNA complexes with nucleotide resolution. Nat. Commun. 2020, 11, 1-10. [CrossRef]

52. Bai, X.C.; Martin, T.G.; Scheres, S.H.; Dietz, H. Cryo-EM structure of a 3D DNA-origami object. Proc. Natl. Acad. Sci. USA 2012, 109, 20012-20017. [CrossRef]

53. Zhan, P.; Urban, M.J.; Both, S.; Duan, X.; Kuzyk, A.; Weiss, T.; Liu, N. DNA-assembled nanoarchitectures with multiple components in regulated and coordinated motion. Sci. Adv. 2019, 5, eaax6023. [CrossRef]

54. Marras, A.E.; Zhou, L.; Su, H.J.; Castro, C.E. Programmable motion of DNA origami mechanisms. Proc. Natl. Acad. Sci. USA 2015, 112, 713-718. [CrossRef] [PubMed]

55. Yurke, B.; Turberfield, A.J.; Mills, A.P.; Simmel, F.C.; Neumann, J.L. A DNA-fuelled molecular machine made of DNA. Nature 2000, 406, 605-608. [CrossRef]

56. Ryssy, J.; Natarajan, A.K.; Wang, J.; Lehtonen, A.J.; Nguyen, M.K.; Klajn, R.; Kuzyk, A. Light-Responsive Dynamic DNA-OrigamiBased Plasmonic Assemblies. Angew. Chem. Int. Ed. 2020. [CrossRef]

57. Zhang, D.Y.; Seelig, G. Dynamic DNA nanotechnology using strand-displacement reactions. Nat. Chem. 2011, 3, 103-113. [CrossRef]

58. Simmel, F.C.; Yurke, B.; Singh, H.R. Principles and applications of nucleic acid strand displacement reactions. Chem. Rev. 2019, 119, 6326-6369. [CrossRef]

59. Douglas, S.M.; Bachelet, I.; Church, G.M. A logic-gated nanorobot for targeted transport of molecular payloads. Science 2012, 335, 831-834. [CrossRef] [PubMed]

60. Yin, P.; Yan, H.; Daniell, X.G.; Turberfield, A.J.; Reif, J.H. A unidirectional DNA walker that moves autonomously along a track. Angew. Chem. 2004, 116, 5014-5019. [CrossRef]

61. Zhou, L.; Marras, A.E.; Su, H.J.; Castro, C.E. DNA origami compliant nanostructures with tunable mechanical properties. ACS Nano 2014, 8, 27-34. [CrossRef] [PubMed]

62. Lee, C.; Lee, J.Y.; Kim, D.N. Polymorphic design of DNA origami structures through mechanical control of modular components. Nat. Commun. 2017, 8, 2067. [CrossRef] 
63. Shon, M.J.; Rah, S.H.; Yoon, T.Y. Submicrometer elasticity of double-stranded DNA revealed by precision force-extension measurements with magnetic tweezers. Sci. Adv. 2019, 5, eaav1697. [CrossRef] [PubMed]

64. Suzuki, Y.; Kawamata, I.; Mizuno, K.; Murata, S. Large Deformation of a DNA-Origami Nanoarm Induced by the Cumulative Actuation of Tension-Adjustable Modules. Angew. Chem. Int. Ed. 2020, 59, 6230-6234. [CrossRef] [PubMed]

65. Song, J.; Li, Z.; Wang, P.; Meyer, T.; Mao, C.; Ke, Y. Reconfiguration of DNA molecular arrays driven by information relay. Science 2017, 357. [CrossRef]

66. Wang, D.; Yu, L.; Huang, C.M.; Arya, G.; Chang, S.; Ke, Y. Programmable Transformations of DNA Origami Made of Small Modular Dynamic Units. J. Am. Chem. Soc. 2021, 143, 2256-2263. [CrossRef]

67. Takenaka, T.; Endo, M.; Suzuki, Y.; Yang, Y.; Emura, T.; Hidaka, K.; Kato, T.; Miyata, T.; Namba, K.; Sugiyama, H. Photoresponsive DNA nanocapsule having an open/close system for capture and release of nanomaterials. Chem. A Eur. J. 2014, 20, 14951-14954. [CrossRef] [PubMed]

68. Kohman, R.E.; Han, X. Light sensitization of DNA nanostructures via incorporation of photo-cleavable spacers. Chem. Commun. 2015, 51, 5747-5750. [CrossRef]

69. Wang, J.; Yue, L.; Li, Z.; Zhang, J.; Tian, H.; Willner, I. Active generation of nanoholes in DNA origami scaffolds for programmed catalysis in nanocavities. Nat. Commun. 2019, 10,1-10. [CrossRef] [PubMed]

70. Dong, Y.; Yang, Z.; Liu, D. DNA nanotechnology based on i-motif structures. Acc. Chem. Res. 2014, 47, 1853-1860. [CrossRef]

71. Turek, V.A.; Chikkaraddy, R.; Cormier, S.; Stockham, B.; Ding, T.; Keyser, U.F.; Baumberg, J.J. Thermo-Responsive Actuation of a DNA Origami Flexor. Adv. Funct. Mater. 2018, 28, 1706410. [CrossRef]

72. Kopperger, E.; List, J.; Madhira, S.; Rothfischer, F.; Lamb, D.C.; Simmel, F.C. A self-assembled nanoscale robotic arm controlled by electric fields. Science 2018, 359, 296-301. [CrossRef]

73. Jiang, Q.; Song, C.; Nangreave, J.; Liu, X.; Lin, L.; Qiu, D.; Wang, Z.G.; Zou, G.; Liang, X.; Yan, H.; et al. DNA origami as a carrier for circumvention of drug resistance. J. Am. Chem. Soc. 2012, 134, 13396-13403. [CrossRef] [PubMed]

74. Kim, H.; Surwade, S.P.; Powell, A.; O'Donnell, C.; Liu, H. Stability of DNA origami nanostructure under diverse chemical environments. Chem. Mater. 2014, 26, 5265-5273. [CrossRef]

75. Martin, T.G.; Dietz, H. Magnesium-free self-assembly of multi-layer DNA objects. Nat. Commun. 2012, 3, 1-6. [CrossRef]

76. Ramakrishnan, S.; Krainer, G.; Grundmeier, G.; Schlierf, M.; Keller, A. Structural stability of DNA origami nanostructures in the presence of chaotropic agents. Nanoscale 2016, 8, 10398-10405. [CrossRef]

77. Ke, Y.; Bellot, G.; Voigt, N.V.; Fradkov, E.; Shih, W.M. Two design strategies for enhancement of multilayer-DNA-origami folding: underwinding for specific intercalator rescue and staple-break positioning. Chem. Sci. 2012, 3, 2587-2597. [CrossRef] [PubMed]

78. Gerling, T.; Kube, M.; Kick, B.; Dietz, H. Sequence-programmable covalent bonding of designed DNA assemblies. Sci. Adv. 2018, 4, eaau1157. [CrossRef] [PubMed]

79. Zhang, Q.; Jiang, Q.; Li, N.; Dai, L.; Liu, Q.; Song, L.; Wang, J.; Li, Y.; Tian, J.; Ding, B.; et al. DNA origami as an in vivo drug delivery vehicle for cancer therapy. ACS Nano 2014, 8, 6633-6643. [CrossRef] [PubMed]

80. Liu, X.; Zhang, F.; Jing, X.; Pan, M.; Liu, P.; Li, W.; Zhu, B.; Li, J.; Chen, H.; Wang, L.; et al. Complex silica composite nanomaterials templated with DNA origami. Nature 2018, 559, 593-598. [CrossRef]

81. Nguyen, M.K.; Nguyen, V.H.; Natarajan, A.K.; Huang, Y.; Ryssy, J.; Shen, B.; Kuzyk, A. Ultrathin silica coating of DNA origami nanostructures. Chem. Mater. 2020, 32, 6657-6665. [CrossRef]

82. Jin, Z.; Sun, W.; Ke, Y.; Shih, C.J.; Paulus, G.L.; Wang, Q.H.; Mu, B.; Yin, P.; Strano, M.S. Metallized DNA nanolithography for encoding and transferring spatial information for graphene patterning. Nat. Commun. 2013, 4, 1-9. [CrossRef]

83. Wang, S.T.; Gray, M.A.; Xuan, S.; Lin, Y.; Byrnes, J.; Nguyen, A.I.; Todorova, N.; Stevens, M.M.; Bertozzi, C.R.; Zuckermann, R.N.; et al. DNA origami protection and molecular interfacing through engineered sequence-defined peptoids. Proc. Natl. Acad. Sci. USA 2020, 117, 6339-6348. [CrossRef]

84. Kiviaho, J.K.; Linko, V.; Ora, A.; Tiainen, T.; Järvihaavisto, E.; Mikkilä, J.; Tenhu, H.; Kostiainen, M.A. Cationic polymers for DNA origami coating-examining their binding efficiency and tuning the enzymatic reaction rates. Nanoscale 2016, 8, 11674-11680. [CrossRef]

85. Ponnuswamy, N.; Bastings, M.M.; Nathwani, B.; Ryu, J.H.; Chou, L.Y.; Vinther, M.; Li, W.A.; Anastassacos, F.M.; Mooney, D.J.; Shih, W.M. Oligolysine-based coating protects DNA nanostructures from low-salt denaturation and nuclease degradation. Nat. Commun. 2017, 8, 1-9. [CrossRef] [PubMed]

86. Auvinen, H.; Zhang, H.; Kopilow, A.; Niemelä, E.H.; Nummelin, S.; Correia, A.; Santos, H.A.; Linko, V.; Kostiainen, M.A. Protein coating of DNA nanostructures for enhanced stability and immunocompatibility. Adv. Healthc. Mater. 2017, 6, 1700692. [CrossRef] [PubMed]

87. Bila, H.; Kurisinkal, E.E.; Bastings, M.M. Engineering a stable future for DNA-origami as a biomaterial. Biomater. Sci. 2019, 7, 532-541. [CrossRef] [PubMed]

88. Ramakrishnan, S.; Ijäs, H.; Linko, V.; Keller, A. Structural stability of DNA origami nanostructures under application-specific conditions. Comput. Struct. Biotechnol. J. 2018, 16, 342-349. [CrossRef] [PubMed]

89. Lodish, H.; Berk, A.; Kaiser, C.A.; Kaiser, C.; Krieger, M.; Scott, M.P.; Bretscher, A.; Ploegh, H.; Matsudaira, P. Molecular Cell Biology; WH Freeman: New York, NY, USA, 2013; Volume 7.

90. Tanner, P.; Baumann, P.; Enea, R.; Onaca, O.; Palivan, C.; Meier, W. Polymeric vesicles: From drug carriers to nanoreactors and artificial organelles. Acc. Chem. Res. 2011, 44, 1039-1049. [CrossRef] [PubMed] 
91. Xu, C.; Hu, S.; Chen, X. Artificial cells: From basic science to applications. Mater. Today 2016, 19, 516-532. [CrossRef]

92. Sun, W.; Boulais, E.; Hakobyan, Y.; Wang, W.L.; Guan, A.; Bathe, M.; Yin, P. Casting inorganic structures with DNA molds. Science 2014, 346, 1258361. [CrossRef] [PubMed]

93. Helmi, S.; Ziegler, C.; Kauert, D.J.; Seidel, R. Shape-controlled synthesis of gold nanostructures using DNA origami molds. Nano Lett. 2014, 14, 6693-6698. [CrossRef] [PubMed]

94. Gao, C.; Zhang, Q.; Lu, Z.; Yin, Y. Templated synthesis of metal nanorods in silica nanotubes. J. Am. Chem. Soc. 2011, 133, 19706-19709. [CrossRef] [PubMed]

95. Giessen, T.W.; Silver, P.A. Converting a natural protein compartment into a nanofactory for the size-constrained synthesis of antimicrobial silver nanoparticles. ACS Synth. Biol. 2016, 5, 1497-1504. [CrossRef]

96. Bayrak, T.; Helmi, S.; Ye, J.; Kauert, D.; Kelling, J.; Schönherr, T.; Weichelt, R.; Erbe, A.; Seidel, R. DNA-mold templated assembly of conductive gold nanowires. Nano Lett. 2018, 18, 2116-2123. [CrossRef] [PubMed]

97. Li, S.; Jiang, Q.; Liu, S.; Zhang, Y.; Tian, Y.; Song, C.; Wang, J.; Zou, Y.; Anderson, G.J.; Han, J.Y.; et al. A DNA nanorobot functions as a cancer therapeutic in response to a molecular trigger in vivo. Nat. Biotechnol. 2018, 36, 258. [CrossRef]

98. Burns, J.R.; Stulz, E.; Howorka, S. Self-assembled DNA nanopores that span lipid bilayers. Nano Lett. 2013, 13, 2351-2356. [CrossRef] [PubMed]

99. Grossi, G.; Jepsen, M.D.E.; Kjems, J.; Andersen, E.S. Control of enzyme reactions by a reconfigurable DNA nanovault. Nat. Commun. 2017, 8, 992. [CrossRef] [PubMed]

100. Voigt, N.V.; Tørring, T.; Rotaru, A.; Jacobsen, M.F.; Ravnsbæk, J.B.; Subramani, R.; Mamdouh, W.; Kjems, J.; Mokhir, A.; Besenbacher, F.; et al. Single-molecule chemical reactions on DNA origami. Nat. Nanotechnol. 2010, 5, 200-203. [CrossRef] [PubMed]

101. Derr, N.D.; Goodman, B.S.; Jungmann, R.; Leschziner, A.E.; Shih, W.M.; Reck-Peterson, S.L. Tug-of-war in motor protein ensembles revealed with a programmable DNA origami scaffold. Science 2012, 338, 662-665. [CrossRef]

102. Linko, V.; Eerikäinen, M.; Kostiainen, M.A. A modular DNA origami-based enzyme cascade nanoreactor. Chem. Commun. 2015, 51, 5351-5354. [CrossRef]

103. Fu, Y.; Zeng, D.; Chao, J.; Jin, Y.; Zhang, Z.; Liu, H.; Li, D.; Ma, H.; Huang, Q.; Gothelf, K.V.; et al. Single-step rapid assembly of DNA origami nanostructures for addressable nanoscale bioreactors. J. Am. Chem. Soc. 2013, 135, 696-702. [CrossRef]

104. Zhao, Z.; Fu, J.; Dhakal, S.; Johnson-Buck, A.; Liu, M.; Zhang, T.; Woodbury, N.W.; Liu, Y.; Walter, N.G.; Yan, H. Nanocaged enzymes with enhanced catalytic activity and increased stability against protease digestion. Nat. Commun. 2016, 7, 10619. [CrossRef] [PubMed]

105. Dong, Y.; Chen, S.; Zhang, S.; Sodroski, J.; Yang, Z.; Liu, D.; Mao, Y. Folding DNA into a Lipid-Conjugated Nanobarrel for Controlled Reconstitution of Membrane Proteins. Angew. Chem. 2018, 130, 2094-2098. [CrossRef]

106. Rosenblum, D.; Joshi, N.; Tao, W.; Karp, J.M.; Peer, D. Progress and challenges towards targeted delivery of cancer therapeutics. Nat. Commun. 2018, 9, 1-12. [CrossRef] [PubMed]

107. Franch, O.; Iacovelli, F.; Falconi, M.; Juul, S.; Ottaviani, A.; Benvenuti, C.; Biocca, S.; Ho, Y.P.; Knudsen, B.R.; Desideri, A. DNA hairpins promote temperature controlled cargo encapsulation in a truncated octahedral nanocage structure family. Nanoscale 2016, 8, 13333-13341. [CrossRef] [PubMed]

108. Raniolo, S.; Unida, V.; Vindigni, G.; Stolfi, C.; Iacovelli, F.; Desideri, A.; Biocca, S. Combined and selective miR-21 silencing and doxorubicin delivery in cancer cells using tailored DNA nanostructures. Cell Death Dis. 2021, 12, 1-9. [CrossRef]

109. Song, T.; Shah, S.; Bui, H.; Garg, S.; Eshra, A.; Fu, D.; Yang, M.; Mokhtar, R.; Reif, J. Programming DNA-based biomolecular reaction networks on cancer cell membranes. J. Am. Chem. Soc. 2019, 141, 16539-16543. [CrossRef]

110. Pan, Q.; Nie, C.; Hu, Y.; Yi, J.; Liu, C.; Zhang, J.; He, M.; He, M.; Chen, T.; Chu, X. Aptamer-Functionalized DNA Origami for Targeted Codelivery of Antisense Oligonucleotides and Doxorubicin to Enhance Therapy in Drug-Resistant Cancer Cells. ACS Appl. Mater. Interfaces 2019, 12, 400-409. [CrossRef]

111. Langecker, M.; Arnaut, V.; Martin, T.G.; List, J.; Renner, S.; Mayer, M.; Dietz, H.; Simmel, F.C. Synthetic lipid membrane channels formed by designed DNA nanostructures. Science 2012, 338, 932-936. [CrossRef]

112. Burns, J.R.; Göpfrich, K.; Wood, J.W.; Thacker, V.V.; Stulz, E.; Keyser, U.F.; Howorka, S. Lipid-bilayer-spanning DNA nanopores with a bifunctional porphyrin anchor. Angew. Chem. Int. Ed. 2013, 52, 12069-12072. [CrossRef]

113. Diederichs, T.; Pugh, G.; Dorey, A.; Xing, Y.; Burns, J.R.; Nguyen, Q.H.; Tornow, M.; Tampé, R.; Howorka, S. Synthetic protein-conductive membrane nanopores built with DNA. Nat. Commun. 2019, 10, 1-11. [CrossRef] [PubMed]

114. Burns, J.R.; Seifert, A.; Fertig, N.; Howorka, S. A biomimetic DNA-based channel for the ligand-controlled transport of charged molecular cargo across a biological membrane. Nat. Nanotechnol. 2016, 11, 152-156. [CrossRef] [PubMed]

115. Thomsen, R.P.; Malle, M.G.; Okholm, A.H.; Krishnan, S.; Bohr, S.S.R.; Sørensen, R.S.; Ries, O.; Vogel, S.; Simmel, F.C.; Hatzakis, N.S.; et al. A large size-selective DNA nanopore with sensing applications. Nat. Commun. 2019, 10, 1-10. [CrossRef] [PubMed]

116. Iric, K.; Subramanian, M.; Oertel, J.; Agarwal, N.P.; Matthies, M.; Periole, X.; Sakmar, T.P.; Huber, T.; Fahmy, K.; Schmidt, T.L. DNA-encircled lipid bilayers. Nanoscale 2018, 10, 18463-18467. [CrossRef]

117. Sinden, R.R. DNA Structure and Function; Gulf Professional Publishing: Houston, TX, USA, 1994.

118. Perrault, S.D.; Shih, W.M. Virus-inspired membrane encapsulation of DNA nanostructures to achieve in vivo stability. ACS Nano 2014, 8, 5132-5140. [CrossRef] [PubMed] 
119. Dong, Y.; Yang, Y.R.; Zhang, Y.; Wang, D.; Wei, X.; Banerjee, S.; Liu, Y.; Yang, Z.; Yan, H.; Liu, D. Cuboid vesicles formed by frame-guided assembly on DNA origami scaffolds. Angew. Chem. Int. Ed. 2017, 56, 1586-1589. [CrossRef] [PubMed]

120. Zhang, Z.; Yang, Y.; Pincet, F.; Llaguno, M.C.; Lin, C. Placing and shaping liposomes with reconfigurable DNA nanocages. Nat. Chem. 2017, 9, 653-659. [CrossRef]

121. Has, C.; Sunthar, P. A comprehensive review on recent preparation techniques of liposomes. J. Liposome Res. 2020, $30,336-365$. [CrossRef]

122. Yang, Y.; Wang, J.; Shigematsu, H.; Xu, W.; Shih, W.M.; Rothman, J.E.; Lin, C. Self-assembly of size-controlled liposomes on DNA nanotemplates. Nat. Chem. 2016, 8, 476-483. [CrossRef]

123. Denisov, I.G.; Sligar, S.G. Nanodiscs for structural and functional studies of membrane proteins. Nat. Struct. Mol. Biol. 2016, 23, 481-486. [CrossRef]

124. Zhao, Z.; Zhang, M.; Hogle, J.M.; Shih, W.M.; Wagner, G.; Nasr, M.L. DNA-corralled nanodiscs for the structural and functional characterization of membrane proteins and viral entry. J. Am. Chem. Soc. 2018, 140, 10639-10643. [CrossRef]

125. Wickham, S.F.; Auer, A.; Min, J.; Ponnuswamy, N.; Woehrstein, J.B.; Schueder, F.; Strauss, M.T.; Schnitzbauer, J.; Nathwani, B.; Zhao, Z.; et al. Complex multicomponent patterns rendered on a 3D DNA-barrel pegboard. Nat. Commun. 2020, 11, 1-10. [CrossRef]

126. Sun, W.; Shen, J.; Zhao, Z.; Arellano, N.; Rettner, C.; Tang, J.; Cao, T.; Zhou, Z.; Ta, T.; Streit, J.K.; et al. Precise pitch-scaling of carbon nanotube arrays within three-dimensional DNA nanotrenches. Science 2020, 368, 874-877. [CrossRef] [PubMed]

127. Raab, M.; Jusuk, I.; Molle, J.; Buhr, E.; Bodermann, B.; Bergmann, D.; Bosse, H.; Tinnefeld, P. Using DNA origami nanorulers as traceable distance measurement standards and nanoscopic benchmark structures. Sci. Rep. 2018, 8, 1-11. [CrossRef]

128. Bian, X.; Zhang, Z.; Xiong, Q.; De Camilli, P.; Lin, C. A programmable DNA-origami platform for studying lipid transfer between bilayers. Nat. Chem. Biol. 2019, 15, 830-837. [CrossRef] [PubMed]

129. Franquelim, H.G.; Khmelinskaia, A.; Sobczak, J.P.; Dietz, H.; Schwille, P. Membrane sculpting by curved DNA origami scaffolds. Nat. Commun. 2018, 9, 1-10. [CrossRef] [PubMed]

130. Grome, M.W.; Zhang, Z.; Pincet, F.; Lin, C. Vesicle Tubulation with Self-Assembling DNA Nanosprings. Angew. Chem. Int. Ed. 2018, 57, 5330-5334. [CrossRef] [PubMed]

131. Franquelim, H.G.; Dietz, H.; Schwille, P. Reversible membrane deformations by straight DNA origami filaments. Soft Matter 2021, 17, 276-287. [CrossRef]

132. Johnson-Buck, A.; Jiang, S.; Yan, H.; Walter, N.G. DNA-cholesterol barges as programmable membrane-exploring agents. ACS Nano 2014, 8, 5641-5649. [CrossRef]

133. Ambrosetti, E.; Bernardinelli, G.; Hoffecker, I.; Hartmanis, L.; Kiriako, G.; De Marco, A.; Sandberg, R.; Högberg, B.; Teixeira, A.I. A DNA-nanoassembly-based approach to map membrane protein nanoenvironments. Nat. Nanotechnol. 2020, 16, 85-95 [CrossRef]

134. Feng, L.; Li, J.; Sun, J.; Wang, L.; Fan, C.; Shen, J. Recent Advances of DNA Nanostructure-Based Cell Membrane Engineering. Adv. Healthc. Mater. 2021, 2001718. [CrossRef]

135. Martin, T.G.; Bharat, T.A.; Joerger, A.C.; Bai, X.C.; Praetorius, F.; Fersht, A.R.; Dietz, H.; Scheres, S.H. Design of a molecular support for cryo-EM structure determination. Proc. Natl. Acad. Sci. USA 2016, 113, E7456-E7463. [CrossRef] [PubMed]

136. Zhang, H.; Chao, J.; Pan, D.; Liu, H.; Qiang, Y.; Liu, K.; Cui, C.; Chen, J.; Huang, Q.; Hu, J.; et al. DNA origami-based shape IDs for single-molecule nanomechanical genotyping. Nat. Commun. 2017, 8, 1-7. [CrossRef]

137. Ke, Y.; Lindsay, S.; Chang, Y.; Liu, Y.; Yan, H. Self-assembled water-soluble nucleic acid probe tiles for label-free RNA hybridization assays. Science 2008, 319, 180-183. [CrossRef]

138. Korpelainen, V.; Linko, V.; Seppä, J.; Lassila, A.; Kostiainen, M.A. DNA origami structures as calibration standards for nanometrology. Meas. Sci. Technol. 2017, 28, 034001. [CrossRef]

139. Zanacchi, F.C.; Manzo, C.; Alvarez, A.S.; Derr, N.D.; Garcia-Parajo, M.F.; Lakadamyali, M. A DNA origami platform for quantifying protein copy number in super-resolution. Nat. Methods 2017, 14, 789-792. [CrossRef] [PubMed]

140. Schmied, J.J.; Forthmann, C.; Pibiri, E.; Lalkens, B.; Nickels, P.; Liedl, T.; Tinnefeld, P. DNA origami nanopillars as standards for three-dimensional superresolution microscopy. Nano Lett. 2013, 13, 781-785. [CrossRef]

141. Dickerson, M.B.; Sandhage, K.H.; Naik, R.R. Protein-and peptide-directed syntheses of inorganic materials. Chem. Rev. 2008, 108, 4935-4978. [CrossRef] [PubMed]

142. Alivisatos, A.P.; Johnsson, K.P.; Peng, X.; Wilson, T.E.; Loweth, C.J.; Bruchez, M.P.; Schultz, P.G. Organization of'nanocrystal molecules' using DNA. Nature 1996, 382, 609-611. [CrossRef] [PubMed]

143. Mirkin, C.A.; Letsinger, R.L.; Mucic, R.C.; Storhoff, J.J. A DNA-based method for rationally assembling nanoparticles into macroscopic materials. Nature 1996, 382, 607-609. [CrossRef]

144. Dujardin, E.; Peet, C.; Stubbs, G.; Culver, J.N.; Mann, S. Organization of metallic nanoparticles using tobacco mosaic virus templates. Nano Lett. 2003, 3, 413-417. [CrossRef]

145. Kumara, M.T.; Tripp, B.C.; Muralidharan, S. Self-assembly of metal nanoparticles and nanotubes on bioengineered flagella scaffolds. Chem. Mater. 2007, 19, 2056-2064. [CrossRef]

146. Schreiber, R.; Luong, N.; Fan, Z.; Kuzyk, A.; Nickels, P.C.; Zhang, T.; Smith, D.M.; Yurke, B.; Kuang, W.; Govorov, A.O.; et al. Chiral plasmonic DNA nanostructures with switchable circular dichroism. Nat. Commun. 2013, 4, 2948. [CrossRef]

147. Jiang, Q.; Liu, Q.; Shi, Y.; Wang, Z.G.; Zhan, P.; Liu, J.; Liu, C.; Wang, H.; Shi, X.; Zhang, L.; et al. Stimulus-responsive plasmonic chiral signals of gold nanorods organized on DNA origami. Nano Lett. 2017, 17, 7125-7130. [CrossRef] 
148. Huang, Y.; Nguyen, M.K.; Natarajan, A.K.; Nguyen, V.H.; Kuzyk, A. A DNA origami-based chiral plasmonic sensing device. ACS Appl. Mater. Interfaces 2018, 10, 44221-44225. [CrossRef]

149. Shen, X.; Asenjo-Garcia, A.; Liu, Q.; Jiang, Q.; García de Abajo, F.J.; Liu, N.; Ding, B. Three-dimensional plasmonic chiral tetramers assembled by DNA origami. Nano Lett. 2013, 13, 2128-2133. [CrossRef] [PubMed]

150. Lan, X.; Lu, X.; Shen, C.; Ke, Y.; Ni, W.; Wang, Q. Au nanorod helical superstructures with designed chirality. J. Am. Chem. Soc. 2015, 137, 457-462. [CrossRef]

151. Zhou, C.; Duan, X.; Liu, N. A plasmonic nanorod that walks on DNA origami. Nat. Commun. 2015, 6, 1-6. [CrossRef] [PubMed]

152. Zhan, P.; Dutta, P.K.; Wang, P.; Song, G.; Dai, M.; Zhao, S.X.; Wang, Z.G.; Yin, P.; Zhang, W.; Ding, B.; et al. Reconfigurable three-dimensional gold nanorod plasmonic nanostructures organized on DNA origami tripod. ACS Nano 2017, 11, 1172-1179. [CrossRef] [PubMed]

153. Kuzyk, A.; Yang, Y.; Duan, X.; Stoll, S.; Govorov, A.O.; Sugiyama, H.; Endo, M.; Liu, N. A light-driven three-dimensional plasmonic nanosystem that translates molecular motion into reversible chiroptical function. Nat. Commun. 2016, 7, 1-6. [CrossRef]

154. Yan, W.; Xu, L.; Xu, C.; Ma, W.; Kuang, H.; Wang, L.; Kotov, N.A. Self-assembly of chiral nanoparticle pyramids with strong R/S optical activity. J. Am. Chem. Soc. 2012, 134, 15114-15121. [CrossRef]

155. Pilo-Pais, M.; Watson, A.; Demers, S.; LaBean, T.; Finkelstein, G. Surface-enhanced Raman scattering plasmonic enhancement using DNA origami-based complex metallic nanostructures. Nano Lett. 2014, 14, 2099-2104. [CrossRef]

156. Zhan, P.; Wen, T.; Wang, Z.g.; He, Y.; Shi, J.; Wang, T.; Liu, X.; Lu, G.; Ding, B. DNA Origami Directed Assembly of Gold Bowtie Nanoantennas for Single-Molecule Surface-Enhanced Raman Scattering. Angew. Chem. Int. Ed. 2018, 57, 2846-2850. [CrossRef] [PubMed]

157. Wang, P.; Gaitanaros, S.; Lee, S.; Bathe, M.; Shih, W.M.; Ke, Y. Programming self-assembly of DNA origami honeycomb two-dimensional lattices and plasmonic metamaterials. J. Am. Chem. Soc. 2016, 138, 7733-7740. [CrossRef] [PubMed]

158. Trofymchuk, K.; Glembockyte, V.; Grabenhorst, L.; Steiner, F.; Vietz, C.; Close, C.; Pfeiffer, M.; Richter, L.; Schütte, M.L.; Selbach, F.; et al. Addressable nanoantennas with cleared hotspots for single-molecule detection on a portable smartphone microscope. Nat. Commun. 2021, 12, 1-8. [CrossRef] [PubMed]

159. Zhu, C.; Wang, M.; Dong, J.; Zhou, C.; Wang, Q. Modular Assembly of Plasmonic Nanoparticles Assisted by DNA Origami. Langmuir 2018, 34, 14963-14968. [CrossRef]

160. Sun, S.; Yang, S.; Xin, H.L.; Nykypanchuk, D.; Liu, M.; Zhang, H.; Gang, O. Valence-programmable nanoparticle architectures. Nat. Commun. 2020, 11, 1-10. [CrossRef]

161. Liu, W.; Tagawa, M.; Xin, H.L.; Wang, T.; Emamy, H.; Li, H.; Yager, K.G.; Starr, F.W.; Tkachenko, A.V.; Gang, O. Diamond family of nanoparticle superlattices. Science 2016, 351, 582-586. [CrossRef]

162. Tian, Y.; Zhang, Y.; Wang, T.; Xin, H.L.; Li, H.; Gang, O. Lattice engineering through nanoparticle-DNA frameworks. Nat. Mater. 2016, 15, 654-661. [CrossRef]

163. Schreiber, R.; Santiago, I.; Ardavan, A.; Turberfield, A.J. Ordering gold nanoparticles with DNA origami nanoflowers. ACS Nano 2016, 10, 7303-7306. [CrossRef] [PubMed]

164. Zhao, M.; Chen, Y.; Wang, K.; Zhang, Z.; Streit, J.K.; Fagan, J.A.; Tang, J.; Zheng, M.; Yang, C.; Zhu, Z.; et al. DNA-directed nanofabrication of high-performance carbon nanotube field-effect transistors. Science 2020, 368, 878-881. [CrossRef]

165. Jia, S.; Wang, J.; Xie, M.; Sun, J.; Liu, H.; Zhang, Y.; Chao, J.; Li, J.; Wang, L.; Lin, J.; et al. Programming DNA origami patterning with non-canonical DNA-based metallization reactions. Nat. Commun. 2019, 10, 1-9. [CrossRef] [PubMed]

166. Shen, B.; Linko, V.; Tapio, K.; Pikker, S.; Lemma, T.; Gopinath, A.; Gothelf, K.V.; Kostiainen, M.A.; Toppari, J.J. Plasmonic nanostructures through DNA-assisted lithography. Sci. Adv. 2018, 4, eaap8978. [CrossRef]

167. Hirokawa, N.; Noda, Y.; Tanaka, Y.; Niwa, S. Kinesin superfamily motor proteins and intracellular transport. Nat. Rev. Mol. Cell Biol. 2009, 10, 682-696. [CrossRef]

168. Cheng, C.; Stoddart, J.F. Wholly synthetic molecular machines. ChemPhysChem 2016, 17, 1780-1793. [CrossRef] [PubMed]

169. Sauvage, J.P. From chemical topology to molecular machines (Nobel lecture). Angew. Chem. Int. Ed. 2017, 56, 11080-11093. [CrossRef]

170. Stoddart, J.F. Mechanically interlocked molecules (MIMs)—Molecular shuttles, switches, and machines (Nobel Lecture). Angew. Chem. Int. Ed. 2017, 56, 11094-11125. [CrossRef]

171. Kosuri, P.; Altheimer, B.D.; Dai, M.; Yin, P.; Zhuang, X. Rotation tracking of genome-processing enzymes using DNA origami rotors. Nature 2019, 572, 136-140. [CrossRef]

172. Zhou, L.; Gao, M.; Fu, W.; Wang, Y.; Luo, D.; Chang, K.; Chen, M. Three-dimensional DNA tweezers serve as modular DNA intelligent machines for detection and regulation of intracellular microRNA. Sci. Adv. 2020, 6, eabb0695. [CrossRef] [PubMed]

173. Kuzuya, A.; Sakai, Y.; Yamazaki, T.; Xu, Y.; Komiyama, M. Nanomechanical DNA origami'single-molecule beacons' directly imaged by atomic force microscopy. Nat. Commun. 2011, 2, 1-8. [CrossRef]

174. Koirala, D.; Shrestha, P.; Emura, T.; Hidaka, K.; Mandal, S.; Endo, M.; Sugiyama, H.; Mao, H. Single-molecule mechanochemical sensing using DNA origami nanostructures. Angew. Chem. 2014, 126, 8275-8279. [CrossRef]

175. Funke, J.J.; Ketterer, P.; Lieleg, C.; Schunter, S.; Korber, P.; Dietz, H. Uncovering the forces between nucleosomes using DNA origami. Sci. Adv. 2016, 2, e1600974. [CrossRef]

176. Zhu, D.; Pei, H.; Yao, G.; Wang, L.; Su, S.; Chao, J.; Wang, L.; Aldalbahi, A.; Song, S.; Shi, J.; et al. A surface-confined proton-driven DNA pump using a dynamic 3D DNA scaffold. Adv. Mater. 2016, 28, 6860-6865. [CrossRef] [PubMed] 
177. Karna, D.; Stilgenbauer, M.; Jonchhe, S.; Ankai, K.; Kawamata, I.; Cui, Y.; Zheng, Y.R.; Suzuki, Y.; Mao, H. Chemo-Mechanical Modulation of Cell Motions Using DNA Nanosprings. Bioconjug. Chem. 2021, 32, 311-317. [CrossRef] [PubMed]

178. Iwaki, M.; Wickham, S.; Ikezaki, K.; Yanagida, T.; Shih, W. A programmable DNA origami nanospring that reveals force-induced adjacent binding of myosin VI heads. Nat. Commun. 2016, 7, 1-10. [CrossRef] [PubMed]

179. Kishi, J.Y.; Schaus, T.E.; Gopalkrishnan, N.; Xuan, F.; Yin, P. Programmable autonomous synthesis of single-stranded DNA. Nat. Chem. 2018, 10, 155. [CrossRef]

180. Praetorius, F.; Kick, B.; Behler, K.L.; Honemann, M.N.; Weuster-Botz, D.; Dietz, H. Biotechnological mass production of DNA origami. Nature 2017, 552, 84-87. [CrossRef]

181. Coleridge, E.L.; Dunn, K.E. Assessing the cost-effectiveness of DNA origami nanostructures for targeted delivery of anti-cancer drugs to tumours. Biomed. Phys. Eng. Express 2020, 6, 065030. [CrossRef]

182. Thubagere, A.J.; Li, W.; Johnson, R.F.; Chen, Z.; Doroudi, S.; Lee, Y.L.; Izatt, G.; Wittman, S.; Srinivas, N.; Woods, D.; et al. A cargo-sorting DNA robot. Science 2017, 357. [CrossRef]

183. Ke, Y.; Meyer, T.; Shih, W.M.; Bellot, G. Regulation at a distance of biomolecular interactions using a DNA origami nanoactuator. Nat. Commun. 2016, 7, 1-8. [CrossRef] [PubMed]

184. Yin, Y.; Chen, G.; Gong, L.; Ge, K.; Pan, W.; Li, N.; Machuki, J.O.; Yu, Y.; Geng, D.; Dong, H.; et al. DNAzyme-powered three-dimensional DNA walker nanoprobe for detection amyloid $\beta$-peptide oligomer in living cells and in vivo. Anal. Chem. 2020, 92, 9247-9256. [CrossRef] [PubMed]

185. Suzuki, Y.; Endo, M.; Sugiyama, H. Lipid-bilayer-assisted two-dimensional self-assembly of DNA origami nanostructures. Nat. Commun. 2015, 6, 1-9. [CrossRef] [PubMed]

186. Matsuda, K.; Kabir, A.M.R.; Akamatsu, N.; Saito, A.; Ishikawa, S.; Matsuyama, T.; Ditzer, O.; Islam, M.S.; Ohya, Y.; Sada, K.; et al. Artificial smooth muscle model composed of hierarchically ordered microtubule asters mediated by DNA origami nanostructures. Nano Lett. 2019, 19, 3933-3938. [CrossRef] [PubMed] 